\title{
What are the consequences of global banking for the international transmission of shocks? A quantitative analysis*
}

\author{
José L. Fillat ${ }^{\dagger}$ \\ Stefania Garetto ${ }^{\ddagger}$ \\ Arthur V. Smith ${ }^{\S}$ \\ Federal Reserve Bank of Boston \\ Boston U., CEPR, and NBER \\ Boston U.
}

October 25, 2018

\begin{abstract}
The global financial crisis of 2008 was followed by a wave of regulatory reforms that affected large banks, especially those with a global presence. These reforms were reactive to the crisis. In this paper we propose a structural model of global banking that can be used proactively to perform counterfactual analysis on the effects of alternative regulatory policies. The structure of the model mimics the US regulatory framework and highlights the organizational choices that banks face when entering a foreign market: branching versus subsidiarization. When calibrated to match moments from a sample of European banks, the model is able to replicate the response of the US banking sector to the European sovereign debt crisis. Our counterfactual analysis suggests that pervasive subsidiarization, higher capital requirements, or ad hoc monetary policy interventions would have mitigated the effects of the crisis on US lending.
\end{abstract}

Keywords: global banks, banking regulation, shock transmission.

JEL Classification: F12, F23, F36, G21

\footnotetext{
${ }^{*}$ We are grateful to Andrew Bernard, Nicola Cetorelli, Jean-Edouard Colliard, Enrique Martinez-García, Linda Goldberg, Victoria Ivashina, Andrei Levchenko, Friederike Niepmann, Joe Peek, Katheryn Russ, Jeremy Stein, and seminar participants at many institutions for helpful comments. We also thank Martin Götz for invaluable input at the initial stages of this project. Andrew Barton, Kovid Puria, and Marco Sammon provided excellent research assistance.

${ }^{\dagger}$ Federal Reserve Bank of Boston, 600 Atlantic Avenue, Boston MA 02210. E-mail: Jose.Fillat@bos.frb.org. The views expressed in this paper are those of the authors and do not necessarily reflect those of the Federal Reserve Bank of Boston or Federal Reserve System.

${ }^{\ddagger}$ Department of Economics, Boston University, 270 Bay State Road, Boston, MA 02215. E-mail: garettos@bu.edu.

${ }^{\S}$ Department of Economics, Boston University, 270 Bay State Road, Boston, MA 02215. E-mail: avsmith@bu.edu.
} 


\section{Introduction}

The 2008 global financial crisis and-more recently-the European sovereign debt crisis have spurred debates among academics and policymakers about the regulation of large, systemically important banks. Most of the institutions under scrutiny are multinational banks, with operations in multiple countries, raising concerns about contagion and shock transmission. Arguably, regulatory reforms should be not only reactive to crises, but also designed ex-ante to reduce the likelihood and limit the severity of such crises.

In this paper, we inform the design of multinational banking regulation by developing a quantitative structural model of global banking and by using it to evaluate the effects of counterfactual policies. We focus our analysis on global banks because they are often the largest players in the countries where they operate: as noted by Goldberg (2009), the sheer size of foreign banking institutions and their involvement with the real economy makes them important vehicles for the global transmission of shocks. For example, the Japanese banking crisis in the early 1990s had a substantial effect on credit supply in the United States, as many US branches and subsidiaries of Japanese banks shrank their US operations, and in some cases closed down, following the shock in their home country. The European sovereign debt crisis also had rippling effects in the US credit markets, mostly due to the fragility of foreign branches' funding, as our empirical analysis shows below. Several empirical studies have explored the role of multinational banks in the transmission of shocks across countries 1 Our paper contributes to this literature in two ways. First, while prior contributions have overlooked the importance of a bank's mode of operations, our model provides a microfoundation for the bank's decision of whether and how to enter a foreign market - through branches or subsidiaries. We find that this differentiation is of first-order importance to understanding the effects of financial crises. Second, while most of the existing work has been conducted using reduced-form analysis, our quantitative model enables us to study the consequences of potential regulatory changes via counterfactual analysis.

The model we develop is designed to describe the institutional details of the banking industry and to be consistent with a number of stylized facts from US bank-level data. For this reason, our analysis focuses on the two most prominent forms of foreign banking institutions in the United States: branches and subsidiaries. Current US bank regulations treat foreign-owned branches and subsidiaries differently, so the activities that a branch and a subsidiary are allowed to undertake

\footnotetext{
${ }^{1}$ See most notably Cetorelli and Goldberg $(2011,2012 \mathrm{a}, \mathrm{b})$.
} 
differ: for example, while subsidiaries are separately capitalized, branches do not raise independent equity and are subject to capital requirements at the parent bank level. While subsidiaries can issue all types of deposits, branches can issue only uninsured wholesale deposits. Finally, unlike subsidiaries, branches can freely transfer funds to and from their parent 2

The distinction between branches and subsidiaries is important, both for the selection of different banks in these two organizational modes, and for their different responses to shocks. We show that the European parents of global banking conglomerates with affiliates in the United States tend to be larger than those European banks without operations in the United States. Moreover, the parent banking organizations of foreign subsidiaries are systematically larger than the parent banks of foreign branches. At the affiliate level, subsidiaries also are larger than branches. These size rankings hold when evaluated in terms of deposits, loans, and total assets. To study the extent of shock transmission, we analyze the response of US-based affiliates of European banks to the European sovereign debt crisis. We find that, in the wake of the crisis, US branches of exposed European banks experienced a flight in their uninsured deposits, while deposits at subsidiaries (both insured and uninsured) grew. Because the shortage of funding that branches experienced was only partially compensated by intrafirm transfers of funds from their parents, US branches of exposed European banks experienced a decrease in their assets. At the same time, assets increased in exposed US subsidiaries. These facts inform the construction of the model.

The bank's problem is modeled as a monopolistically competitive extension of the Monti-Klein model (see Klein 1971, and Monti 1972), augmented to include institutional features like capital requirements and deposit insurance. The model explicitly distinguishes among foreign banking institutions by their mode of operations, which is endogenous and responds to differences in the regulatory environment and in bank management efficiency. This feature allows us to assess whether the mode of operations matters for the severity of shocks' transmission across countries. The model features the channels of adjustment that we document in the data, and its simple structure is amenable to quantification. We calibrate the model to match a set of cross-sectional moments of the US foreign banking sector and show that our calibrated economy generates responses to shocks that are consistent with the actual responses of multinational banks to the European sovereign debt crisis. We then use the model to perform counterfactual exercises that shed light on the quantitative implications of current and counterfactual banking regulations for the transmission of

\footnotetext{
${ }^{2}$ In the remainder of this paper, as an analogy to the literature on multinational corporations, we refer to a parent bank, or just parent, as the home-based banking organization. Branches are owned by a bank, while subsidiaries may be owned by a bank or directly by a bank holding company.
} 
shocks across countries.

Our baseline quantitative exercise consists of an analysis of the European sovereign debt crisis. In the model, the crisis is isomorphic to a sudden decline in the probability of loan repayment in Europe. This decline reduces European banks' profits and equity accumulation, lowers their equity to risk-weighted assets ratio, and tightens the banks' buffer on capital requirements. To examine the effect of this change in the balance sheets of European banks on the operations of their US-based affiliates, we model deposit supply following the empirical evidence reported in Egan. Hortacsu, and Matvos (2017): on the one hand, a tightening in global conglomerates' capital reduces the supply of wholesale deposits, which represents a funding shock for US branches. Faced with solvency problems in their foreign branches, European parents use their internal capital market to support profitable lending in their US branches. Nonetheless, US branches decrease their total assets. On the other hand, foreign subsidiaries' balance sheets are more isolated from the shock that affects their parents. As a result, there is no direct effect on their assets and liabilities.

The model is conceptually simple, yet rich in its depiction of the regulatory framework. Given its success at replicating the observed response of foreign banking organizations (henceforth, FBOs) to the European sovereign debt crisis, we use the model to simulate the response to the crisis under counterfactual policy scenarios. The results of our exercises suggest that increased capital requirements, the elimination of branching, or an ad hoc monetary policy intervention would have mitigated the negative effects of the crisis on US aggregate lending. Conversely, the elimination of subsidiarization would have caused an even more severe decline in banking activity in the United States.

Our model also has interesting implications about the possible response of FBOs to "large" shocks to their parents. More precisely, frictions to the internal capital market between parents and subsidiaries imply that, following a "large" shock, a parent bank may decide to repatriate funds by shutting down its foreign subsidiaries. The parents of branches do not have the same incentives, as they can freely repatriate funds through their internal capital market. As an external validation of this mechanism, we show that subsidiaries are more likely than branches to exit a foreign market, and that exits are more common in periods when the parents' equity positions are declining 3

Taken together, the results illustrate the consequences that different organizational forms have for the transmission of financial shocks across countries. Subsidiarization isolates a global bank's

\footnotetext{
${ }^{3}$ Subsidiary exits are typically executed as asset sales to domestic banks, not necessarily as closures or liquidations.
} 
balance sheets by location; hence, it minimizes cross-country contagion. However, by not having access to a fluid internal capital market within the conglomerate, subsidiaries do not provide an effective instrument to dampen the global effect of shocks, resulting in possible reorganizations and exits 4 Conversely, parent-branch conglomerates can more easily take advantage of their internal capital market, smooth the intensity of shocks across countries, and reduce their global impact.

This paper is related to a large empirical literature that studies the role of global banks as vehicles of shock transmission across countries. In a seminal contribution, Peek and Rosengren (2000) have shown the role that US-based branches of Japanese banks played in transmitting the effect of the Japanese banking crisis to the United States. In a similar spirit, Cetorelli and Goldberg (2011) document a decline in lending by foreign affiliates of global banks in emerging economies in the wake of the 2007-2009 financial crisis. Cetorelli and Goldberg (2012a, b) point to the internal capital markets of global banking conglomerates as a channel that strongly contributed to spreading financial shocks during the 2007-2009 crisis. The possibility that parents and branches transfer funds across borders but within the boundaries of the bank holding company is a feature of primary importance in the framework that we present in this paper.

By presenting stylized facts about the features distinguishing multinational from nonmultinational banks, our analysis is also closely related to Claessens, Demirgüç-Kunt, and Huizinga (2001) and Niepmann (2018). Our structural model focuses on two alternative forms of foreign banking: branching and subsidiarization. In this dimension, our work is related to Cerutti, Dell'Ariccia, and Pería (2007), Dell'Ariccia and Marquez (2010), Fiechter et al. (2011), and Danisewicz, Reinhardt, and Sowerbutts (2017). Some of the facts that we report, related to changes in foreign branches' balance sheets in the wake of the European sovereign debt crisis, are present also in Correa. Sapriza, and Zlate (2016). We explicitly compare changes in branches' balance sheets to changes in the balance sheets of subsidiaries.

There is a small but growing literature that uses tools from international trade theory to study the operations of multinational banks. The seminal paper by Eaton (1994) sets the direction for structural research on this topic, but the first contributions to this agenda are in the pioneering work by Niepmann (2015, 2018). Our framework shares with Niepmann (2018) the emphasis on within-country bank heterogeneity and on the role of endogenous selection to understand aggregate outcomes in the global banking sector. The role of bank heterogeneity is also prominent in

\footnotetext{
${ }^{4}$ Internal capital markets are not fluid in that capital transfers from subsidiaries to their parents are limited by capital requirements set by the subsidiary's host-country regulator.
} 
de Blas and Russ (2013) and Bremus et al. (2013), which both show evidence of granularity in the banking sector. Finally, this paper shares with Corbae and D'Erasmo (2013) the emphasis on using quantitative analysis to understand features of the banking data.

There has been an increasing concern about the unintended cross-border effects of policy actions, and global banks play an important role in the international transmission of shocks. In an empirical analysis of the spillovers of national banking regulations across borders, Berrospide et al. (2017) find that tighter banking regulations shift lending away from countries where the tightening occurs. In particular, subsidiaries and branches of banks domiciled in the tightening country play an important role in the transmission mechanism. A similar argument is made in Ongena, Owen, and Temesvary (2018), who study the transmission of US monetary policy across borders through the foreign lending operations of multinational banks headquartered in the United States. We contribute to this literature by examining the potential effects of alternative banking regulations in our quantitative analysis.

The remainder of the paper is organized as follows. Section 2 illustrates the data and documents stylized facts about foreign banking institutions operating in the US market. Section 3 develops a simple model that illustrates the decisions that multinational banks face. The model is then calibrated and used to perform counterfactual exercises in Section 4 . Section 5 concludes.

\section{Foreign Banks in the United States: Stylized Facts}

\section{$2.1 \quad$ Data}

This analysis relies on bank-level data obtained from a variety of sources. Our main source is the Quarterly Report of Condition and Income that every US bank is required to file (also known as "Call Reports"). In addition to domestic banks, US-based subsidiaries of foreign banks must fill out these reports as well 5 We also use the quarterly "Report of Assets and Liabilities of US Branches and Agencies of Foreign Banks" that every branch and agency of a foreign bank is required to

\footnotetext{
${ }^{5}$ The Federal Financial Institutions Examination Council (FFIEC) collects these data in two different reporting forms: FFIEC 031 and FFIEC 041. Banks with foreign offices must file the FFIEC 031 form and banks with only domestic offices must file the FFIEC 041 form. The information about domestic operations is identical across reports for all practical purposes. Appendix A summarizes the US regulatory framework and the changes it underwent in the past decades, with special focus on those regulations that had an impact on foreign banks operating in the United States. Changes to these regulations do not affect the approach and classification that we use in this paper.
} 
file. 6 Call Reports data include detailed information about a foreign bank's US operations, and the ultimate owner's identity, which allows us to distinguish US-based entities belonging to foreignowned global banks from US-owned banks.

In order to have a full picture of global banks' operations at home and abroad, we merge the Call Reports data with two additional data sources: S\&P Global Market Intelligence, which provides regulatory reporting data and accounting data filed by the foreign parents of US-based subsidiaries and branches, and the reported sovereign debt holdings of European banks provided as part of the European Banking Authority's (EBA) Stress Test information. As a result of this data merger, we obtain a sample of 56 European banks that are the ultimate owners of US-based affiliates. At the ultimate owner level, we consolidate all the offices of the same type (i.e., all subsidiaries and all branches). These merged data allow us to present evidence about the response to shocks by different entities of the same global banking conglomerate that are located in different countries.

Since the core of our empirical analysis focuses on how global banks responded to the European sovereign debt crisis, we restrict our sample period to 2007-2013.

\subsection{The Cross-Section of Foreign Banks}

Foreign institutions have a substantial presence in the US banking market. Of the aggregate assets held by banks operating in the United States, between 15 and 20 percent belong to banking offices that are ultimately owned by a foreign parent. Foreign-owned banking offices account for about 20 percent of total deposits and between 20 and 30 percent of total commercial and industrial loans in the United States (see Figure C.1 in the Appendix for more details).

What are the activities of FBOs in the United States? The answer is complex, as a foreign bank may operate in the US market under different organizational forms, associated with very different activities and-most importantly_different regulations. A foreign bank may open a subsidiary bank, which for most purposes operates as a domestically owned US banking entity. A subsidiary is subject to US regulation, raises independent equity, and is subject to independent capital requirements. A subsidiary may accept both wholesale deposits and retail deposits insured by the Federal Deposit Insurance Corporation (FDIC).7 Any capital flows between the subsidiary and the

\footnotetext{
${ }^{6}$ Form FFIEC 002 is similar to the Call Reports, but it also contains the balances "due from" and "due to" the head office (parent) and related depository institutions, wherever located.

${ }^{7}$ Deposits in subsidiaries are classified as retail if they are under the FDIC threshold $(\$ 100,000$ until 2005 and $\$ 250,000$ thereafter). Wholesale deposits are those above the FDIC threshold.
} 
foreign parent must happen "at arm's length," in the form of loans, equity injections, or capital distributions (dividends). This means that if a foreign parent wants to transfer funds to or from a subsidiary in the United States, there is no fluid internal channel to do so 8 In our dataset, we count 47 US-based subsidiaries of foreign banks, with total assets of approximately $\$ 1.16 \mathrm{tn}$, which represent 7.1 percent of all bank assets in the United States. Out of these 47 subsidiaries, 17 are ultimately owned by European banks, with total assets of $\$ 0.68 \mathrm{tn}$ in the United States.

The other most common form of operations is via branching: a branch is also subject to US regulations, but unlike a subsidiary does not raise independent equity. A branch is only subject to capital requirements at the conglomerate level in its home country (i.e., branch assets are consolidated with the foreign parent assets when evaluating the conglomerate's capital ratio). Branches may make loans, but may only accept uninsured wholesale deposits 9 Unlike subsidiaries, branches have an intrafirm channel to transfer capital flows to/from the parent, and do display large intrafirm capital flows with their foreign parents (more on this below). In our dataset, there are 182 US-based branches of foreign banks, with total assets of approximately $\$ 2.19 \mathrm{tn}$, which represent 15 percent of all bank assets in the United States. Out of these 182 US-based branches, 62 are ultimately owned by European banks, with total assets of $\$ 1.19 \operatorname{tn}$ in the United States.

Subsidiaries and branches are the two most common ways that foreign banks operate in the US banking system. Taken together, subsidiaries and branches represent more than 99 percent of the assets held by foreign-owned banking offices. In terms of business lines, these two forms of entry also entail activities that are close to those of traditional banks 10

Our description of the foreign banking sector in the United States begins by showing that there is selection by size akin to what is observed for multinational firms operating in nonbanking sectors. Figure 1 compares European parents of US-based FBOs and European banks without US

\footnotetext{
${ }^{8}$ Equity injections are rare and subject to the home regulator. Equity flows to the parent are in the form of dividend distributions, which are limited by earnings and are typically semiannual. Recently, these distributions are even more limited by the performance in the stress testing exercise for those subsidiaries with more than $\$ 50$ billion in assets.

${ }^{9}$ Branches do not have their own balance sheet, as it is consolidated into the balance sheet of the parent institution. Branches do not have a capital account, and are not required to report income statement variables. Nonetheless, the US regulatory framework requires foreign-owned branches and agencies to report their assets and liabilities in the FFIEC 002 form.

${ }^{10}$ In addition to branches and subsidiaries, the data display two more types of organizations. Edge and agreement corporations cannot engage in business in the United States with US-based entities and are precluded from making domestic loans or accepting domestic deposits. Representative offices and nondepository trusts do not accept deposits or give loans, and their asset holdings are negligible compared with the other types of foreign entities. Given their small weight in aggregate banking activities, we drop edge and agreement corporations, representative offices, and nondepository trusts from our sample and focus the analysis on foreign-owned branches and subsidiaries.
} 

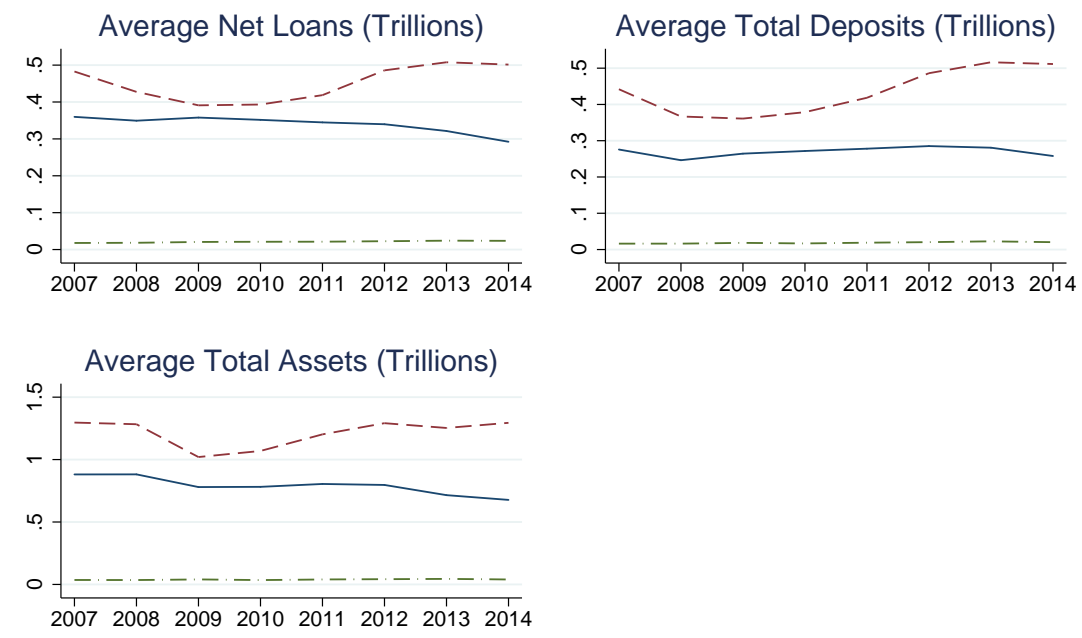

\begin{tabular}{|ll|}
\hline- Parent of US Branch $\quad-----$ Parent of US Subsidiary \\
\hline$-\ldots$ Other European Bank
\end{tabular}

Figure 1: Foreign Parents versus Foreign Nonmultinational Banks

Comparison of size measures of foreign parents of US-based FBOs (subsidiaries and branches) versus European banks without US operations. Data are in trillions of US dollars.

Source: S\&P Global Market Intelligence data for top-tier parents of US branches and subsidiaries from Europe.

operations in terms of loans, deposits, and overall assets 11 It is evident that the European banks that enter the US market through affiliates are larger than the ones that do not 12 Niepmann (2018) presents evidence of a similar pecking order based on bank efficiency (computed as the ratio of overhead costs to total assets). Multinational banks appear to be systematically more efficient than nonmultinational banks. The model that we present in the next section features a positive relationship between bank efficiency and bank size, consistent with Figure 1, The figure further distinguishes parents of foreign subsidiaries from parents of foreign branches, and shows that the parents of foreign subsidiaries are on average larger banks compared with the parents of foreign branches.

\footnotetext{
${ }^{11}$ The assets side of a bank's balance sheet includes many types of loans: wholesale (commercial and industrial loans, real estate loans, and loans to other financial institutions) and retail (mortgages, home equity, auto loans, and credit cards). In addition, other assets held by banks are securities (US treasuries, residential and commercial mortgage-backed securities, other asset-backed securities, and a small amount of stocks) and trading assets. The liabilities side includes deposits, short-term and long-term debt, and owners' equity.

${ }^{12}$ To properly argue about selection by size, ideally we would be comparing foreign parents of US-based FBOs and foreign banks without operations abroad. Unfortunately, the available data do not allow us to distinguish foreign nonmultinational banks from foreign parents of FBOs located in countries other than the United States. However, we argue that since the United States is one of the most popular markets for the activities of multinational banks, if foreign banks do not have US operations, it is unlikely that they have significant operations in other foreign markets.
} 

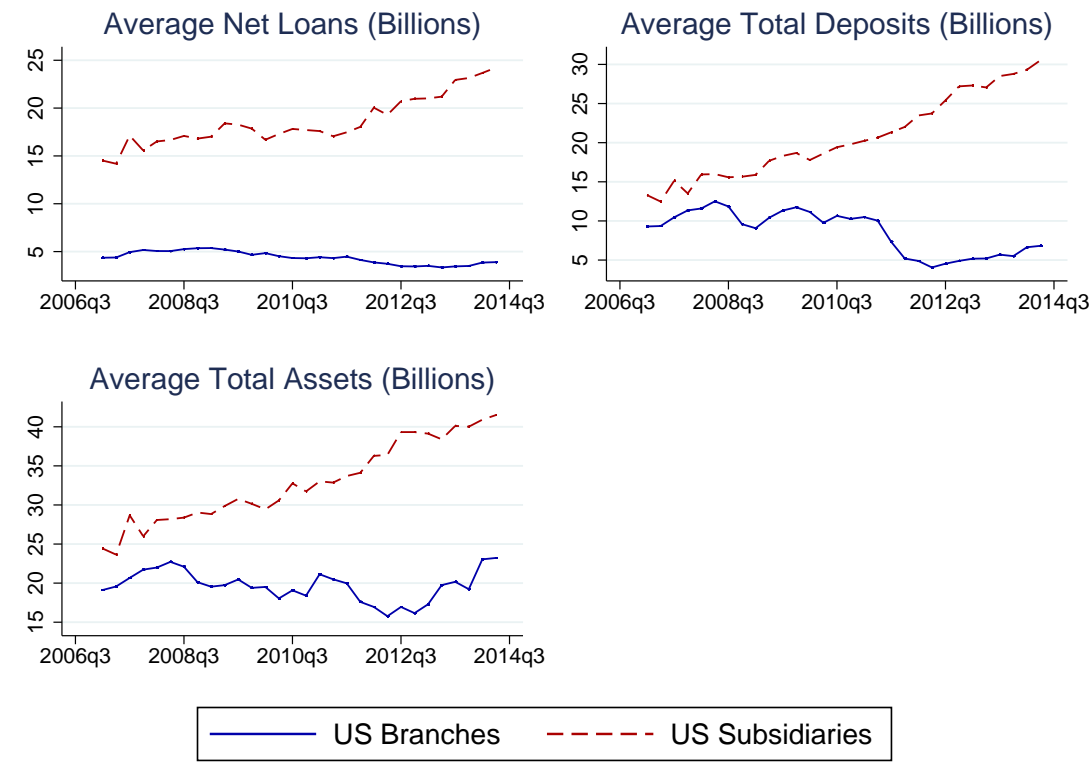

Figure 2: US-Based Branches versus US-Based Subsidiaries of Foreign Banks

Comparison of size measures of US-based subsidiaries and branches of FBOs. Data are in billions of US dollars.

Source: US Structure Data for US Offices of Foreign Banking Organizations - Selected Assets and Liabilities of Domestic and Foreign-Owned US Commercial Banks plus US Branches and Agencies of Foreign Banks.

At the affiliate level, there are large size differences between subsidiaries and branches of FBOs. Figure 2 reports the average size of deposits, loans, and overall assets held by a US branch or subsidiary of a European bank. When comparing FBOs, the average subsidiary is substantially larger than the average branch in terms of deposits, loans, and overall assets. Size differences are persistent over the sample period, and are not driven by a few firms with extraordinarily large balance sheets: the deposits, loans, and assets size distributions of foreign subsidiaries first-order stochastically dominate the analogous distributions of foreign branches (see Figure C.2 in the Appendix).

Finally, Figure C.3 in the Appendix shows that the amount of assets foreign banks hold in the United States is positively related to their domestic size, indicating that banks that are "big" in their home country also have large foreign operations. This fact motivates an important assumption of the model: that banks transfer their efficiency to their foreign affiliates. 


\subsection{Foreign Banks' Response to Shocks}

We use the European sovereign debt crisis as a natural experiment to analyze how global banks respond to shocks and the extent to which these institutions transmit shocks across countries. The analysis in this section is similar in spirit to the one in Cetorelli and Goldberg (2012b) and Correa. Sapriza, and Zlate (2016), but with an emphasis on the distinction between foreign subsidiaries and foreign branches operating in the United States. In a nutshell, we find that after the European sovereign debt crisis: 1) US-based branches of exposed European banks reduced their assets in the United States while US-based subsidiaries of exposed European banks did not experience a decline in assets; 2) the probability that a US branch received an intrafirm transfer from an exposed parent increased, and the amount of the transfer increased; and 3) there was a flight of uninsured wholesale deposits from the US branches of exposed European parents, while both the insured and uninsured deposits of US subsidiaries of exposed European parents were not affected.

We start by assessing the differential response of branches versus subsidiaries by looking at their assets. For this purpose, we run the following regression:

$$
a_{b, t}^{e}=\alpha+\beta_{1} \text { Crisis }_{t}+\beta_{2} \operatorname{Exp}_{b}+\beta_{3} \operatorname{Crisis}_{t} \times \operatorname{Exp}_{b}+\delta_{c}+\varepsilon_{b, t}^{e}
$$

where $a_{b, t}^{e}$ is the natural $\log$ of total assets of entity $e$ belonging to bank $b$ at time $t$. An entity is either an aggregate of US-based branches or an aggregate of US-based subsidiaries belonging to a European banking conglomerate $b$. We run the regression separately for branches and for subsidiaries. The dummy variable Crisis $t_{t}$ takes the value of 1 for all quarter-years after 2011 (included), while the dummy variable $\operatorname{Exp}_{b}$ takes the value of 1 when parent bank $b$ of entity $e$ is exposed to Greek, Italian, Irish, Portuguese, or Spanish (GIIPS) sovereign debt. We classify a bank as exposed if it has GIIPS sovereign debt holdings above the sample median 13 The regression includes parent country fixed effects, denoted by $\delta_{c}$, to exploit variation in asset holdings across banks from the same host country. The results are reported in Table 1 and show that, after the

\footnotetext{
${ }^{13}$ The chain of events in 2010 resulted in a fear of contagion regarding sovereign default in the GIIPS countries which, at the same time, fueled concerns about the stability of the euro and the euro zone more broadly. As Figure C.4 in the Appendix illustrates, exposed banks were headquartered in many countries in Europe, not only the GIIPS. Our results are robust to alternative definitions of exposed banks. In particular, we also performed the empirical analysis reported in this section using the following alternative definitions of "exposed parent": i) classify a bank as exposed if it has positive GIIPS sovereign debt holdings, ii) classify a bank as exposed if from a country in the euro zone. We define exposure using these coarse dummies rather than using exposure levels as explanatory variables because GIIPS sovereign debt holdings constitute a very small share of these banks' balance sheets: among exposed parents, the mean (median) exposure is only 3.07 percent (1.7 percent) of assets. For this reason, we do not think that variation in the intensive margin of exposure drives the different responses of banks to the crisis.
} 
Table 1: Intensive Margin of Assets: Branches versus Subsidiaries

\begin{tabular}{lcc}
\hline & \multicolumn{2}{c}{$\ln ($ Total Assets $)$} \\
\hline & Subsidiaries & Branches \\
\hline Crisis & 0.103 & 0.133 \\
& $(0.115)$ & $(0.223)$ \\
Exp & $1.983^{* * *}$ & $1.674^{* *}$ \\
& $(0.351)$ & $(0.724)$ \\
Crisis $\times$ Exp & 0.0847 & $-0.622^{* *}$ \\
& $(0.234)$ & $(0.231)$ \\
Country FE & Yes & Yes \\
\hline No. of Obs. & 914 & 2,683 \\
$R^{2}$ & 0.585 & 0.288 \\
\hline
\end{tabular}

European sovereign debt crisis, US branches of exposed European banks decreased their assets in the United States, while the assets of US subsidiaries of exposed European banks were unaffected 14 The estimated coefficients in the second column of table1 imply that assets held in branches owned by exposed parents experienced a 54 percent decline on average - about $\$ 500$ billion in total, after the crisis. The average decline is comparable to that in Peek and Rosengren (2000), where they estimate the effects of the Japanese crises in the early 1990s. Peek and Rosengren (2000) find that assets held by Japanese branches in California, New York, and Illinois, declined by 53 percent, 50 percent, and 70 percent, respectively, with a total asset contraction of $\$ 42$ billion in 2013 dollars 15

Given that the sovereign debt crisis affected the balance sheets of the European parents of these FBOs, one might think that the drop in assets of their US-based branches was associated with an internal transfer of resources from the United States to Europe. The left panel of Figure 3 shows the evolution of the aggregate net flows to and from related institutions. From 1995 to 2011, the amounts that European parent banks were borrowing from their US branches were much larger than the amounts that US branches were borrowing from their European parents. This pattern is consistent with the evidence shown by Cetorelli and Goldberg (2012a, b) and Correa, Sapriza, and Zlate (2016) about foreign branches being a source of funding to their US parents. The pattern sharply reverts at the onset of the European sovereign debt crisis in 2011. The right panel of Figure 3 illustrates the intrafirm flows broken down between exposed and nonexposed banks. It is evident

\footnotetext{
${ }^{14}$ For robustness, we also run the regression pooling observations of branches and subsidiaries, identifying differential responses to the crisis via triple interaction terms. The results are unchanged. We prefer to present the results of the two separate regressions to ease the interpretation of the coefficients of interest.

${ }^{15}$ Their original estimate is $\$ 28.3$ billion in 1996 dollars.
} 

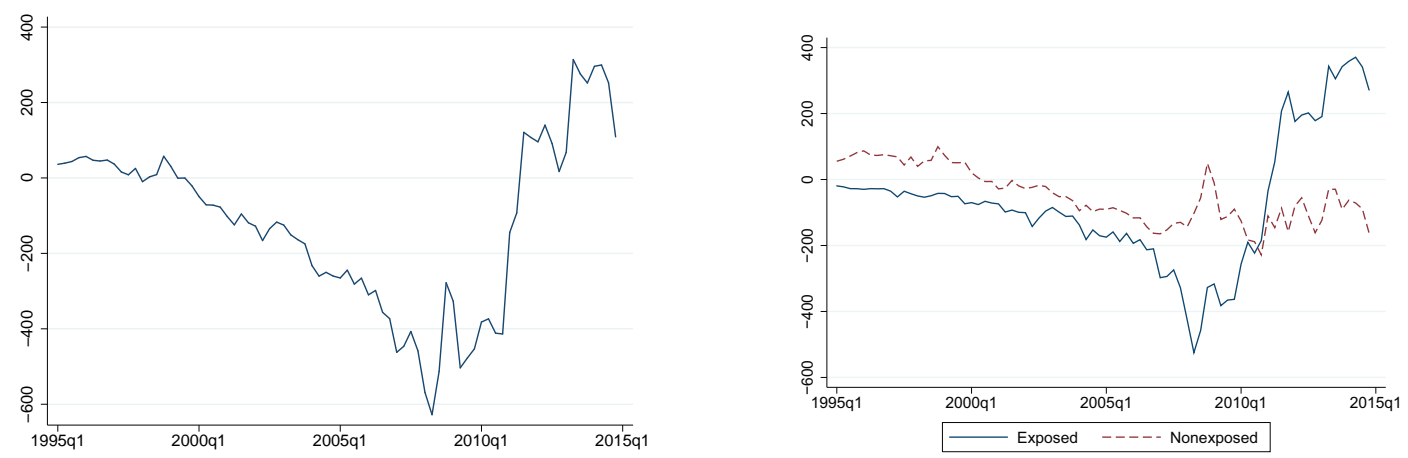

Figure 3: Net Intrafirm Flows for Foreign Branches of European Banks The plot shows the difference between net due from related depository institutions and net due to related depository institutions (items 2 and 5, respectively, from the "Schedule RAL - Assets and Liabilities"). Data are in billions of US dollars.

Source: Report of Assets and Liabilities of US Branches and Agencies of Foreign Banks (FFIEC 002).

from the figure that the sign reversal in intrafirm capital flows between parents and branches is mostly due to FBOs whose parents were exposed to the crisis 16

We run the following regressions to establish more precisely the sharp distinction between intrafirm flows of exposed versus nonexposed European banks with foreign branches:

$$
T_{b, t}^{e}=\alpha+\beta_{1} \operatorname{Crisis}_{t}+\beta_{2} \operatorname{Exp}_{b}+\beta_{3} \operatorname{Crisis}_{t} \times \operatorname{Exp}_{b}+\delta_{c}+\varepsilon_{b, t}^{e} .
$$

To study both the intensive and extensive margin of the intrafirm transfers, $T_{e, b, t}$ is either a dummy variable taking the value one if parent bank $b$ has a claim on branch $e$ 's assets in period $t$ (zero if the branch has a claim on the parent), or the size of the intrafirm transfer of parent bank $b$ to branch $e$ at time $t$. The other variables have been defined above.

The results are reported in Table 2, and show that at the onset of the European sovereign debt crisis, both the intensive and the extensive margin of the intrafirm transfer between a European parent and its US branches were affected as long as the parent was exposed to GIIPS debt. The probability that a US branch received an intrafirm transfer from the exposed parent increased, and the amount of the transfer also increased.

So far we have documented a drop in assets for US branches accompanied by a transfer of resources from the already-exposed European parents to their branches. To shed light on this

\footnotetext{
${ }^{16}$ Figure C.4 in the Appendix illustrates the breakdown of intrafirm flows by origin country.
} 
Table 2: Intensive and Extensive Margin of Intrafirm Transfers between European Parents and their US Branches

\begin{tabular}{lcc}
\hline & $\operatorname{prob}(T>0)$ & $T$ \\
\hline Crisis & $0.283^{* * *}$ & 1,354 \\
& $(0.0522)$ & $(1,301)$ \\
Exp & $-0.854^{* * *}$ & $-11,320^{* * *}$ \\
& $(0.100)$ & $(3,577)$ \\
Crisis $\times$ Exp & $0.949^{* * *}$ & $18,315^{* * *}$ \\
& $(0.170)$ & $(5,081)$ \\
Constant & $0.0810^{* * *}$ & \\
& $(0.0296)$ & \\
Country FE & No & Yes \\
\hline No. of Obs. & 3,000 & 2,976 \\
$R^{2}$ & 0.0333 & 0.176 \\
\hline
\end{tabular}

apparent puzzle, we examine the funding side of US FBOs' balance sheets by running regressions of deposits on a set of dummies that are analogous to the ones previously used:

$$
d_{b, t}^{e}=\alpha+\beta_{1} \operatorname{Crisis}_{t}+\beta_{2} \operatorname{Exp}_{b}+\beta_{3} \operatorname{Crisis}_{t} \times \operatorname{Exp}_{b}+\delta_{c}+\varepsilon_{i, t}^{e},
$$

where $d_{i, t}^{e}$ is the natural log of total deposits of entity $e$ at time $t$. We run three separate regressions: one for retail insured deposits, which are accepted only by subsidiaries, one for wholesale uninsured deposits held by subsidiaries, and one for wholesale uninsured deposits held by branches.

The results are shown in Table 3, Retail deposits in exposed subsidiaries appear to be unaffected by the crisis. More interestingly, the flight in wholesale deposits that other papers have documented appears to be unique to branches owned by exposed European parents. On the contrary, wholesale deposits increased in US subsidiaries owned by exposed European parents. Other paper 17 have documented the flight of wholesale deposits during the European sovereign debt crisis, but did not highlight the different responses depending on the organizational form of the banks accepting them. Table 3 suggests that the flight affected only those wholesale deposits that were held in branches, indicating that this less-regulated organizational form was perceived as less stable by large wholesale depositors.

The results of this analysis depict a scenario in which distress among some European parents was associated with a flight of uninsured deposits from their foreign branches in the United States.

\footnotetext{
${ }^{17}$ See Correa, Sapriza, and Zlate (2016); Egan, Hortacsu, and Matvos (2017).
} 
Table 3: Intensive Margin of Wholesale and Retail Deposits; Branches vs. Subsidiaries

\begin{tabular}{lccc}
\hline & \multicolumn{2}{c}{ Subsidiaries } & Branches \\
\hline & $\ln ($ Retail Deposits $)$ & $\ln$ (Wholesale Deposits) & $\ln$ (Wholesale Deposits) \\
\hline Crisis & $0.403^{* * *}$ & 0.000503 & 0.106 \\
& $(0.154)$ & $(0.138)$ & $(0.241)$ \\
Exp & $1.740^{* * *}$ & $1.581^{* * *}$ & $2.323^{* * *}$ \\
& $(0.469)$ & $(0.421)$ & $(0.309)$ \\
Crisis $\times$ Exp & 0.480 & 0.189 & $-1.340^{* * *}$ \\
& $(0.312)$ & $(0.283)$ & $(0.346)$ \\
\hline Country FE & Yes & Yes & Yes \\
No. of Obs. & 914 & 906 & 2,382 \\
$R^{2}$ & 0.454 & 0.463 & 0.244 \\
\hline
\end{tabular}

The reaction on the funding side of foreign branches has the effect of changing the direction of intrafirm banking flows: foreign branches appeared to be a source of funding to their parents until 2011, while after the crisis parents started acting as a source of funding to their branches. This evidence indicates that branching appears to transmit shocks across countries more than subsidiarization does, as the latter institutional arrangement effectively isolates FBOs from potential distress affecting their parents.

In the next section we introduce a structural model of foreign banking that is consistent with the institutional features of the foreign banking sector in the United States and with the empirical evidence presented so far in this paper.

\section{A Model of Foreign Banking}

This section introduces a simple model that illustrates the main tradeoffs that a bank faces when deciding whether and how to operate in a foreign country. We extend the Monti-Klein model (see Klein 1971, and Monti 1972) to a setting with monopolistic competition among heterogeneous banks, featuring the institutional characteristics of different bank types. The model enables us to understand banks' decisions as responses to various shocks and the consequences of these choices for the banking sector in aggregate, and lays the ground for the quantitative analysis developed in the next section. 


\subsection{Setup}

The model economy is composed of two countries, Home and Foreign. Variables referring to the Foreign country are denoted by an asterisk $(*)$. Each country is populated by a large mass of banks. In addition, each bank may open an affiliate in the other country, either as a branch or as a subsidiary, and thus become the parent of a multinational bank.

In order to examine the effect of shocks like the European sovereign debt crisis, we develop the model with two periods. In the first period, each bank chooses whether and how to operate in the foreign market, makes profits, and accumulates equity. We label a "local bank" as a bank that chooses not to operate in the foreign market. At the end of the first period, an unexpected shock hits the economy, affecting equity accumulation and the decisions banks make in the second period.

We start by modeling the profit maximization problem of a bank conditional on each one of the three international status choices: local bank, parent with foreign subsidiary, or parent with foreign branch. Once the tradeoffs driving a bank's optimal decisions conditional on its status are well understood, we model selection into international status. A bank enters the foreign market if, by doing so, it will make higher profits than if it operated only domestically.

In the domestic market, each bank offers one-period loans $(L)$. With a certain probability of default $(1-p)$ loans are delinquent and the principal is not repaid. Each bank also accepts deposits $(D)$, and borrows/lends in the interbank market $(M)$. We assume that every bank has market power in the market for loans, originating from some type of differentiation (e.g., spatial or product). This differentiation, together with customers' love of variety in banking products, is the rationale for why many banks coexist in the economy. Banks are heterogeneous in the efficiency with which they manage their activities, and operate under monopolistic competition in the market for loans and deposits. For simplicity, the interbank market is assumed to be perfectly competitive. We do not model domestic entry: all banks operate and make nonnegative profits in their home market.

During each period, banks incur a cost to manage deposits and loans described by the cost function $a \cdot C(D, L)$. The bank-specific efficiency parameter $a$ is the source of heterogeneity across banks, and it affects the management cost function multiplicatively, so that "low a" banks are more efficient than "high $a$ " banks. Moreover, each bank is endowed with a given amount of equity $E(a)$, which is a function of bank efficiency. 
In order to assess the importance of regulatory banking policies for the response to shocks, we model deposit insurance and capital requirements. In the United States, for example, all banks accepting retail deposits have to pay deposit insurance to the FDIC, which determines the deposit insurance premium $(I P)$, or assessment, on a risk basis. A bank's assessment is calculated by multiplying its assessment rate by its assessment base, where a bank's assessment base is equal to its average consolidated total assets minus its average tangible equity. In our model, the assessment rate is a function expressing the bank's ability to withstand funding and asset stress, so we assume the assessment rate is a function of the bank's equity and liabilities:

$$
I P(D, L, M)=\underbrace{f_{p}\left(D, M^{-}, E(a)\right)}_{\text {assessment rate }} \cdot \underbrace{\left(L+M^{+}-E(a)\right)}_{\text {assessment base }},
$$

where $M^{+}\left(M^{-}\right)$denotes interbank lending (borrowing) 18

Banks are subject to capital requirements every period, i.e., there is a lower bound on the ratio of equity to risk-weighted assets that they are allowed to sustain:

$$
\frac{E(a)}{\omega_{L} L+\omega_{M} M^{+}} \geq k
$$

where the value of $k$ is set in the United States under the implementation of the Basel II/Basel III Accords. The parameters $\omega_{L}$ and $\omega_{M}$ are appropriate weights that reflect the riskiness of a bank's loans and investments, and are determined by the regulatory agencies (in the US case, by the Federal Reserve, FDIC, and Office of the Comptroller of the Currency).

Based on the evidence presented in Section 2, we assume that when a bank enters the Foreign market, it transfers its efficiency $1 / a$ to the new affiliate. Entering the Foreign market involves a fixed cost, that is higher if the bank enters with a subsidiary rather than a branch: $F_{s}>F_{b}>0$. The fixed costs of opening a subsidiary may include the cost of setting up a network of affiliates, acquiring customers, and learning about the host country's regulatory framework. As the activities of branches are more limited compared to those of subsidiaries, we assume that the fixed cost of branching is lower than the fixed cost of subsidiarization. If a bank enters the Foreign market as a subsidiary, the subsidiary performs exactly the same operations as the parent does in the Home country: it accepts retail deposits, issues loans, makes investments, borrows/lends in the interbank market, holds independent equity, and it is subject to its own capital requirements. We also assume

\footnotetext{
${ }^{18}$ Appendix D contains more institutional details about the calculation of deposit insurance assessments.
} 
that the subsidiary faces operating costs analogous to the ones of the parent.

Conversely, if a bank enters the Foreign market by opening a branch, the activities of the affiliate differ from those of the parent. Branches do not raise independent equity, they are not subject to capital requirements, and can only accept uninsured wholesale deposits. Following Egan, Hortacsu, and Matvos (2017), we assume that the supply of uninsured deposits is less elastic than the supply of insured deposits, and that uninsured deposits are sensitive to a measure of "distress" experienced by the banking corporation, while insured deposits are not similarly affected.

Finally, there exists an intrafirm channel linking the assets and liabilities of the parent and its branch: parents of foreign branches can borrow from or lend to their branches at no cost. Conversely, since transfers between parents and subsidiaries present more frictions, we assume that parents and their subsidiaries can trade only at arm's length via the interbank market.

\subsection{Local Banks}

A local bank chooses the optimal amounts of loans, $L$, interbank activity, $M$, and deposits, $D$, to maximize its profits:

$$
\begin{array}{rlc}
\max _{L, D, M} & p \cdot r_{L}(L) \cdot L-(1-p) L+r_{M} M-r_{D}(D) \cdot D-a C(D, L)-I P(D, L, M) \\
\text { s.t. } & E(a)+D \geq L+M \quad \text { (resource constraint) } \\
& \frac{E(a)}{\omega_{L} L+\omega_{M} M^{+}} \geq k \quad \text { (capital requirement) },
\end{array}
$$

where $r_{L}(L)$, denotes a downward-sloping demand for loans, and $p \in(0,1)$ is the probability of loan repayment. The function $r_{D}(D)$ is an upward-sloping supply of insured retail deposits 19 while $r_{M}$ is the interbank rate, which the bank takes as exogenous, but is endogenously determined in industry equilibrium. Each bank maximizes the profits generated by its activities subject to two constraints. First, its assets must not exceed its liabilities (the resource constraint). Second, the ratio of equity to risk-weighted assets must be maintained above the capital requirement, $k$. Notice also that the bank's management cost and its equity level depend on the bank's efficiency, which is the exogenous source of heterogeneity in the model.

\footnotetext{
${ }^{19}$ In the data, parent banks and their subsidiaries can accept all kinds of deposits, both wholesale and retail. For simplicity, in the model we assume that parent banks and subsidiaries hold only retail deposits. The results are robust to the removal of this simplifying assumption.
} 
In normal times, we observe in the data that banks choose to operate with a buffer on their capital requirements, i.e., capital requirement constraints are normally not binding 20 For this reason, we assume that the equilibrium in normal times is one where the resource constraint binds, but the capital requirement does not. We refer to this solution of the model as the "unconstrained equilibrium." The unconstrained equilibrium is characterized by an interior solution for $(L, D)$, described by the following first-order conditions:

$$
\begin{aligned}
& {[L] \quad p\left[\frac{\partial r_{L}(L)}{\partial L} L+r_{L}(L)\right]=a \frac{\partial C(\cdot)}{\partial L}+\frac{\partial I P(\cdot)}{\partial L}+(1-p)+r_{M}} \\
& {[D] \quad\left[\frac{\partial r_{D}(D)}{\partial D} D+r_{D}(D)\right]+a \frac{\partial C(\cdot)}{\partial D}+\frac{\partial I P(\cdot)}{\partial D}=r_{M}}
\end{aligned}
$$

where the functions' arguments have been omitted to simplify the notation. The resource constraint pins down interbank activity: $M=E(a)+D-L$.

The first-order conditions are intuitive. A bank chooses the optimal amount of loans such that the marginal revenue from lending is equal to the sum of the marginal costs of loans and deposit insurance, the expected marginal loss from delinquent loans, and the opportunity cost of forgone alternatives, namely lending to other financial institutions in the interbank market. Similarly, optimal deposits are set such that their "total" marginal cost, inclusive of management costs and the insurance premium, is equal to the marginal cost of borrowing in the interbank market. In Appendix D, we illustrate that by making some simple parametric assumptions, a bank's maximal profit is an increasing function of the bank's efficiency, 1/a, and the bank's equity, $E(a)$.

In the model, shocks to the economy may induce situations where the capital constraint of a local bank is binding. We refer to this scenario as the model's "constrained equilibrium" and present its detailed solution in Appendix D.

\subsection{The Parent-Subsidiary Pair}

Given that foreign-owned subsidiaries are de facto US banks, a parent-subsidiary pair solves virtually the same profit maximization problem that a local bank faces in each market in which it operates, albeit with two differences: first, upon establishing the subsidiary, the parent transfers a share of its equity, $s_{E} E(a)$, in order for the subsidiary to be initially capitalized. Subsequently, the

\footnotetext{
${ }^{20}$ Figure C.5 in the Appendix shows that banks in our sample have ratios of equity to risk-weighted assets well above the capital requirements set by the regulators.
} 
two entities accumulate equity independently. Second, operating a foreign subsidiary also entails a fixed cost $F_{S}>0$. Hence, a parent-subsidiary pair solves:

$$
\begin{aligned}
\max _{\substack{L, D, M \\
L^{*}, D^{*}, M^{*}}} & \operatorname{pr}_{L}(L) \cdot L-(1-p) L+r_{M} M-r_{D}(D) \cdot D-a C(D, L)-I P(D, L, M)+\ldots \\
& p^{*} r_{L}^{*}\left(L^{*}\right) \cdot L^{*}-\left(1-p^{*}\right) L^{*}+r_{M} M^{*}-r_{D}^{*}\left(D^{*}\right) D^{*}-a C\left(D^{*}, L^{*}\right)-I P\left(D^{*}, L^{*}, M^{*}\right)-F_{S}
\end{aligned}
$$

$$
\begin{array}{ll}
\text { s.t. } & \left(1-s_{E}\right) E(a)+D \geq L+M \\
& s_{E} E(a)+D^{*} \geq L^{*}+M^{*} \\
& \frac{\left(1-s_{E}\right) E(a)}{\omega_{L} L+\omega_{M} M^{+}} \geq k \\
& \frac{s_{E} E(a)}{\omega_{L} L^{*}+\omega_{M} M^{*+}} \geq k,
\end{array}
$$

where asterisks denote foreign-market variables. Notice that all markets are segmented, except for the interbank market, which is a frictionless international market, clearing at the rate $r_{M}$. We also assume that the deposit insurance premium, the capital requirement, and the risk weights on assets are symmetric across countries.

Given that the country-level profit functions associated with the two entities forming the pair are identical, the equilibrium for each entity of a parent-subsidiary pair takes the same form as the equilibrium for a local bank, with the appropriate equity levels, both in the unconstrained and in the constrained case.

\subsection{The Parent-Branch Pair}

When a parent bank enters the Foreign market with a branch, the possibility of intrafirm transfers between parent and branch and the conglomerate's aggregate capital requirement link the decisions of the two entities. A parent-branch pair solves: 


$$
\begin{aligned}
\max _{\substack{L, D, M, T \\
L^{*}, D^{*}}} & \operatorname{pr}_{L}(L) \cdot L-(1-p) L+r_{M} M-r_{D}(D) \cdot D-a C(D, L)-I P(D, L, M)+ \\
& \ldots p^{*} r_{L^{*}}^{*}\left(L^{*}\right) \cdot L^{*}-\left(1-p^{*}\right) L^{*}-r_{D}^{* w}\left(D_{w}^{*} ;\left(\frac{E(a)}{k \cdot R W A}\right)\right) \cdot D_{w}^{*}-a C\left(D_{w}^{*}, L^{*}\right)-F_{B}
\end{aligned}
$$

s.t. $E(a)+D \geq L+M+T$

$$
\begin{aligned}
& D_{w}^{*}+T \geq L^{*} \\
& \frac{E(a)}{\omega_{L}\left(L+L^{*}\right)+\omega_{M} M^{+}} \geq k,
\end{aligned}
$$

where $F_{B}>0$ is the fixed cost of operating a foreign branch, and $T$ is the intrafirm transfer between the two entities ( $T>0$ when the parent is lending to the branch).

The profit function reflects the institutional restrictions that make branches different from local banks and subsidiaries. First, the balance sheet of a branch is effectively "merged" with that of its parent: branches do not raise independent equity, do not operate independently in the interbank market 21 and can transfer funds to/from the parent at no cost $(T)$. As a result, if a branch has excess funds, it may transfer these funds to the parent to finance its domestic lending (as it appears in the pre-crisis period). Similarly, a parent can fund its branch in the event of a shortage of deposits (as it appears in the post-crisis period). Second, the lack of independent equity requirements for branches implies that they are subject to capital requirements only at the level of the entire conglomerate. Finally, on the liabilities side, branches can only accept uninsured wholesale deposits. The term $r_{D}^{* w}\left(D_{w}^{*} ;\left(\frac{E(a)}{k \cdot R W A}\right)\right)$ is the supply of wholesale deposits, where $R W A$ denotes risk-weighted assets: $R W A=\omega_{L}\left(L+L^{*}\right)+\omega_{M} M^{+}$.

We rely on the estimates by Egan, Hortacsu, and Matvos (2017) and assume that the demand for uninsured wholesale deposits is less elastic than the demand for insured retail deposits, and that wholesale deposits are sensitive to some measure of "distress" experienced by the banking organization. Our model-based measure of distress is inversely related to the buffer in the capital requirement that banks hold in normal times, given by the ratio of equity to risk-weighted assets $(R W A)$ divided by the capital requirement $k$. When $\frac{E(a)}{k \cdot R W A}=1$, the capital requirement is binding and the bank experiences maximum distress, resulting in a flight of wholesale deposits. Distress decreases as $\frac{E(a)}{k \cdot R W A}$ grows bigger than one.

\footnotetext{
${ }^{21}$ All interbank activity $M$ is managed by the parent.
} 


\subsection{Industry Equilibrium and Equity Accumulation}

Each country is populated by a continuum of banks that draw their bank-specific efficiency, 1/a, from the exogenous distributions $F(a)$ and $F^{*}(a)$. Selection into the Foreign market implies that there are endogenous equilibrium distributions of banks operating in each country, which we denote with $G(a), G^{*}(a)$.

The interest rate in the interbank market is given by the market-clearing condition:

$$
\int M\left(a ; r_{M}\right) G(a) d a+\int M^{*}\left(a ; r_{M}\right) G^{*}(a) d a=0
$$

Each bank starts the first period with a given level of equity, $E(a)$, and accumulates equity over time through reinvested profits:

$$
E^{\prime}(a)=E(a)+\pi(a)
$$

where $E^{\prime}(a)$ denotes equity in the second period. Finally, banks exit the market if they reach negative equity: if $E^{\prime}(a)<0$ for a local bank or for the parent of a conglomerate, then the entire bank shuts down, while if $E^{\prime}(a)<0$ for a subsidiary, only the subsidiary shuts down.

\subsection{Selection: Matching Cross-Sectional Facts}

The simple model developed in this section is a useful tool to understand the tradeoffs that banks face when entering foreign markets. The combination of bank-level efficiency with fixed and variable costs of operation delivers selection of individual banks into the three possible types: local banks, parent and subsidiary pairs, or parent and branch pairs. Notice that in the model, branching and subsidiarization are alternative choices; hence, no bank chooses both options to operate in a foreign market. This result is consistent with most of the observations in our sample. Among the 47 European banks in our sample, 37 operate in the US market exclusively with branches or exclusively with subsidiaries. Six of the remaining banks adopt both options, but have more than 70 percent of their assets in one organizational form.

The fixed costs associated with foreign operations imply that the largest and most efficient banks become multinational banks, which is consistent with what we observe in the data (see Figure11) and with the features of multinational corporations in other sectors (see Bernard, Jensen, and Schott 2009). For the model to generate selection by size across the different organizational modes of 
multinational banking, there needs to be a tradeoff between the fixed versus variable costs of branching compared to subsidiarization. Particularly, one obtains the observed selection of the most (least) efficient global banks into subsidiarization (branching) if subsidiarization, compared to branching, is associated with lower variable costs but higher fixed costs, as illustrated in Figure 4.

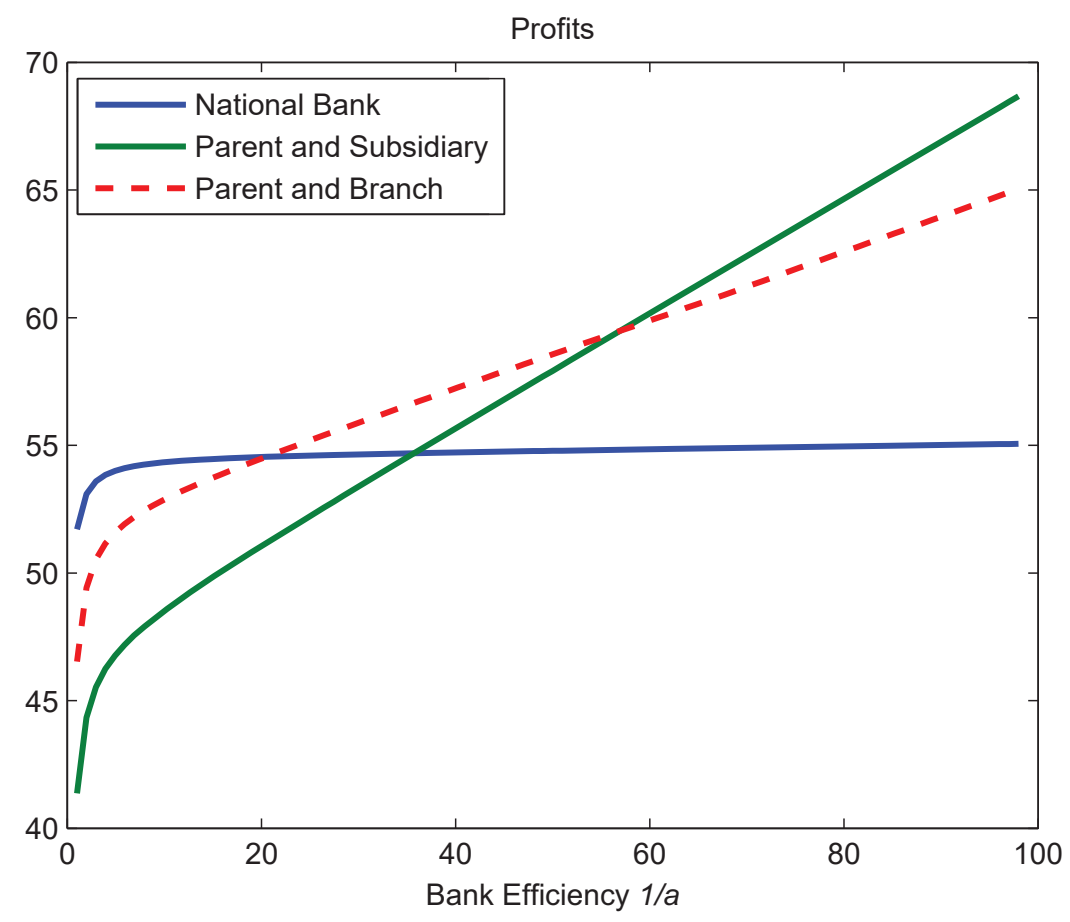

Figure 4: Selection by Efficiency/Size into International and Organizational Status Source: Authors' calculations.

Differences in efficiency then directly translate into differences in the size of deposits, loans, and assets, so that more efficient banks issue more loans, accept more deposits, and have more assets than less efficient banks. By including the relative sizes of different bank types as target moments of our calibration, we ensure that the model generates the same selection pattern that we observe in the data: foreign subsidiaries are larger than foreign branches in terms of loans, deposits, and overall assets. 


\section{Quantitative Analysis}

In this section, we quantify the model in order to use it for counterfactual analysis. We start by calibrating the model to be consistent with the cross-sectional stylized facts presented in Section 2 . The calibrated model is able to reproduce the differential response of global banks with different organizational structures to the shock we studied empirically, the European sovereign debt crisis. To answer a set of policy-relevant questions, we perform a series of counterfactual exercises that shed light on the strength and weaknesses of the current US regulatory framework.

\subsection{Calibration}

Our calibration exercise proceeds in three steps. First, a subset of the model's parameters can be directly matched to empirical observations or to previous studies. Second, we use the empirical distribution of loans to discipline the parameters of the banks' efficiency and equity distributions. Third, we use the model to jointly calibrate the remaining parameters by matching some moments of interest. Since we want to calibrate the economy prior to the European sovereign debt crisis, all the data moments of interest are for the year 2010.

We parameterize the model to preserve tractability and make possible the identification of key parameters. We assume a constant elasticity loan demand function: $L\left(r_{L}\right)=r_{L}^{-\varepsilon} A$, where $\varepsilon>1$ is the elasticity of loan demand, and $A$ is a parameter describing the aggregate size of the loan market. Similarly, we assume a constant-elasticity retail deposit supply function: $D\left(r_{D}\right)=r_{D}^{\vartheta} B$, where $\vartheta>0$ is the elasticity of retail deposit supply, and $B$ is a parameter describing the aggregate size of the retail deposit market. For wholesale deposits, this specification is augmented to generate responses to a measure of the banking conglomerate's distress: $D_{w}\left(r_{D}^{w}\right)=\left(r_{D}^{w}\right)^{\vartheta} w \log \left(\frac{E(a)}{k \cdot R W A}\right) B_{w}$, where $\vartheta_{w}<\vartheta$ is the elasticity of wholesale deposits, and $B_{w}$ is a parameter describing the aggregate size of the wholesale deposit market. This functional form implies that the quantity of deposits supplied decreases as the buffer on the capital requirement decreases, and that there is a complete deposit flight $\left(D_{w}=0\right)$ when the capital requirement is binding. We assume that the management cost function is linear: $C(D, L)=c_{L} L+c_{D} D$, where $c_{L}, c_{D}>0$, and postulate a parametric form for the deposit insurance assessment, which broadly follows the FDIC Current Assessment Rate 
Calculator for Highly Complex Institutions 22

$$
I P(D, L, M)=\left[R_{\min }+f_{p} \cdot \frac{M^{-}}{E(a)}\right] \cdot\left(L+M^{+}-E(a)\right) .
$$

We directly calibrate the parameters $p, R_{m i n}, f_{p}, k, \omega_{L}, \omega_{M}, \vartheta, \vartheta_{w}$, and $s_{E}$. In our model, one minus the probability of loan repayment is equivalent to the bank's expected loss per dollar, which is equal to the probability of default multiplied by the loss given default (one minus the recovery rate). The recovery rate is calibrated to a standard value of 40 percent, which in the event of default implies that $(1-p)=0.4$. In normal times, we calibrate the probability of default to a baseline value of 2.5 percent. This is an approximate middle-range measure based on estimated probabilities of default on debt with credit ratings ranging from AAA to BB 23 Based on these observations, we set the probability of loan repayment (in normal times) to $0.99(1-0.025 \times 0.6)$.

Consistent with the assessment rates reported in Table D.1 in the Appendix, we set $R_{\text {min }}=0.025$ percent to match the minimum possible assessment rate in the scenario in which the bank lends in the interbank market $(M>0)$, while $f_{p}=0.0224$ percent is set such that the bank will be assessed the maximum possible rate if its capital constraint binds and if it relies on the money markets for 95 percent or more of its funding.

We set the capital requirement to $k=0.045$, which is the Basel III capital requirement for common equity over risk-weighted assets. The Basel II/Basel III regulation also gives guidelines on the weights used to compute risk-weighted assets: we choose $\omega_{L}=0.5$, based on corporate loans, consumer loans, and residential mortgage exposures, and $\omega_{M}=0.1$, based on risk weights for exposures to US depository institutions and credit unions.

Egan. Hortacsu, and Matvos (2017) provide structural estimates of the elasticity of supply for both the retail and wholesale deposit market in the United States. Since the way in which we model deposit supply is a special parametric form of what they estimate, we use their estimated elasticities and set $\vartheta=0.56$ and $\vartheta_{w}=0.16$.

Finally, in our dataset, a subsidiary's equity is on average 11 percent of the equity of the parent. As such, we set $s_{E}=0.11$. Table 4 summarizes the parameters that we calibrate directly from the data. We also assume that these parameters are symmetric across the two countries.

\footnotetext{
${ }^{22}$ Appendix D contains more details about these parametric choices.

${ }^{23}$ Source: http://www.newyorkfed.org/research/staff_reports/sr190.pdf.
} 
Table 4: Direct Calibration

\begin{tabular}{llll}
\hline Parameter & Definition & Value & Source \\
\hline$p$ & Probability of Loan Repayment & 0.99 & World Bank \\
$R_{\text {min }}, f_{p}$ & Insurance Premium Parameters & $0.00025,0.000224$ & FDIC \\
$k$ & Capital Requirement & 0.045 & Basel II/III \\
$\omega_{L}, \omega_{M}$ & Risk Weights & $0.5,0.1$ & Basel II/III \\
$s_{E}$ & Subsidiary's Equity Share & 0.11 & Call Reports \\
$\vartheta, \vartheta_{w}$ & Elasticities of Retail and & $0.56,0.16$ & Egan. Hortacsu, and Matvos $(2017)$ \\
\hline
\end{tabular}

In order to discipline the parameters of the banks' efficiency distribution, we start by observing that we cannot reject the hypothesis that the empirical distribution of interest revenues from loans is log-normal. In Appendix E, we show that if the banks' efficiency distribution is log-normal with mean $\mu$ and standard deviation $\sigma$, the distribution of interest revenues from loans is approximately $\log$-normal with mean $\mu_{L}=(\varepsilon-1) \mu+\log \left[\left(\frac{\varepsilon c_{L}}{p(\varepsilon-1)}\right)^{1-\varepsilon} A\right]$ and standard deviation $\sigma_{L}=(\varepsilon-1) \sigma$. Maximum likelihood estimates of the parameters of the empirical distribution of interest revenues from loans deliver $\mu_{L}=5.95$ and $\sigma_{L}=1.93$. Hence, we model a bank's efficiency as a random draw from a log-normal distribution whose parameters $\mu$ and $\sigma$ are calibrated such that:

$$
\begin{aligned}
\mu_{L} & =(\varepsilon-1) \mu+\log \left[\left(\frac{\varepsilon c_{L}}{p(\varepsilon-1)}\right)^{1-\varepsilon} A\right]=5.96 \\
\sigma_{L} & =(\varepsilon-1) \sigma=1.93
\end{aligned}
$$

Banks are heterogeneous, both in their efficiency level and in their equity endowment. Given that we observe nonbinding capital requirements in the data, we target a pre-crisis calibrated economy that is populated by unconstrained banks. The empirical distribution of equity is wellapproximated by a log-normal distribution. Since the model abstracts from uses of equity other than loans, we assume that each bank's pre-crisis equity position is drawn from the same distribution as its loans, scaled by the capital requirement $(k=.045)$ plus a 4 percent capital buffer 24 We impose this buffer because the 2008-2010 period coincides with the implementation of stress testing. As banks were getting ready to undergo stress testing, their ratios of equity to risk-weighted assets increased in this period (see Figure C.5 in the Appendix).

\footnotetext{
${ }^{24}$ We parameterize the buffer as the average hypothetical worst loss that a bank under stress would experience. This assumption ensures that banks are "far" from the constraint in the pre-crisis equilibrium.
} 
It remains to calibrate the relative management cost of loans versus deposits $c_{L} / c_{D}$, the elasticity of loan demand $\varepsilon$, the aggregate parameters of loan demand and deposit supply in each country $\left(A, A^{*}, B, B^{*}, B_{w}\right.$, and $\left.B_{w}^{*}\right)$, and the fixed entry costs $F_{S}$ and $F_{B}$. Since we cannot calibrate these parameters directly, we assume symmetry across countries and use the model to choose values for these parameters in order to match relevant moments from the data. More precisely, we assume that $c_{L} / c_{D}$ and $\varepsilon$ are symmetric across countries; that the relative sizes of loans, retail deposits, and wholesale deposits are the same across countries: $A / A^{*}=B / B^{*}=B_{w} / B_{w}^{*}$; and that fixed costs imply the same distribution of banks by type in each country. Symmetry assumptions also imply a link between the relative sizes of the loan markets in each country and the subsidiary's equity share, so that we are left with seven parameters to be calibrated $\left(c_{L} / c_{D}, \varepsilon, A^{*}, B^{*}, B_{w}^{*}, F_{S}\right.$, and $F_{B}$ ), for which we choose the following set of target moments:

1. The relative size of the average subsidiary/ average branch, in terms of loans;

2. The relative size of the average subsidiary/ average branch, in terms of deposits;

3. The relative presence of foreign branches versus foreign subsidiaries;

4. The share of US loans extended by subsidiaries or branches of foreign banking organizations;

5. The average interest rate on retail deposits;

6. The average interest rate on loans;

7. The average interbank market rate.

The average foreign subsidiary in our data has loans equal to 3.87 times the loans of the average foreign branch, and deposits equal to 1.81 times the deposits of the average foreign branch. In our merged dataset, subsidiaries account for about one-third of US-based FBOs, and in turn FBOs account for about 30 percent of the total loans extended in the United States. As a target for the average interest rate paid on retail deposits, we use a 0.12 percent rate paid on checking accounts. We use LIBOR to pin down the value of the interbank market interest rate, 0.92 percent. Finally, in the model, loans encompass a variety of products, including mortgages, home equity, consumer, and commercial and industrial loans. We take an average for these rates in the data and set our target average interest rates on loans to 6.28 percent.

Table 5 reports the model-generated moments alongside the corresponding moments in the data. The model does a good job at replicating the relative presence of foreign branches versus subsidiaries 
Table 5: Moments: Model versus Data

Parameters are matched to moments for the year 2010.

\begin{tabular}{lll}
\hline Moment & Data & Model \\
\hline Nr. of Subsidiaries/Nr. of Branches & 0.31 & 0.32 \\
Share of US Loans issued by FBOs & $30 \%$ & $35 \%$ \\
Average Subsidiary Loans/Branch Loans & 3.87 & 2.09 \\
Average Subsidiary Deposits/Branch Deposits & 1.81 & 1.39 \\
Avg. Interest Rate On Deposits & $0.12 \%$ & $0.23 \%$ \\
LIBOR One-Year Interbank Rate & $0.92 \%$ & $0.84 \%$ \\
Avg. Interest Rate on Loans & $6.28 \%$ & $7.2 \%$ \\
\hline
\end{tabular}

and the overall size of the foreign banking sector. We underpredict the relative size of loans and deposits, possibly due to an imperfect fit of the parametric efficiency and size distributions. The target interest rates all fit reasonably well. The corresponding calibrated parameters are reported in Table E.1 in the Appendix. The calibration reveals a sizable elasticity of loan demand, $\varepsilon=4.4$, corresponding to an average mark-up of 31 percent. The reported fixed costs imply that the cost of opening a subsidiary (branch) is equal to 52.3 percent ( 82.3 percent) of the average per-period profits of the subsidiary (branch) itself.

Despite its conceptual simplicity, the model is difficult to compute because of the occasionally binding constraints and the consequent presence of corner solutions. As such, it is hard to talk precisely about identification. This said, numerical simulations of the model suggest that the relative number of subsidiaries versus branches and the share of loans issued by FBOs are very sensitive to the calibration of the fixed costs. Moments related to an FBO's relative size are important for quantifying the cost and market size parameters.

\subsection{Global Banks' Organization and the European Sovereign Debt Crisis}

In this section, we use the calibrated model to perform a numerical exercise with the goal of illustrating the consequences of the European sovereign debt crisis for the global banking sector under different policy scenarios.

Starting from the baseline model economy, we simulate the European sovereign debt crisis in two different ways. In the first specification, we introduce an unexpected drop in the probability of loan repayment (to $p^{\prime}=0.964$ ), after banks had decided on their optimal amounts of loans 
and deposits based on the baseline value of $p$. This exercise, which we refer to as a "3.6 percent default," generates an average 10 percent reduction in equity accumulation, similar in size to what we see in the data (see Figure C.5 in the Appendix). In the second specification, we impose a homogeneous 10 percent drop in equity at the end of the first period, with the same average effect, but balanced across all banks. In both exercises, the decline in bank equity reduces banks' buffers on capital requirements: $E(a) / R W A$ decreases. This decline differs across banks according to the concentration of loans in their portfolio allocations.

Table 6 displays the results of this exercise expressed in percentage changes from the baseline pre-crisis economy, reporting both partial equilibrium (keeping the interbank rate $r_{M}$ constant) and industry equilibrium effects (letting $r_{M}$ adjust). The two exercises display similar qualitative effects. The drop in parent equity implies that wholesale deposit supply in US-based branches decreases due to depositors' fears about the health of the conglomerate. In our calibrated economy, the decline in wholesale deposits ranges from 9 percent to 13 percent across the specifications. As branches experience a funding shock, their demand for borrowing increases, and intrafirm borrowing from their parents $(T>0)$ increases from 8 percent to 13 percent across specifications. As we observe in the data, the need for extra funding is not entirely fulfilled by the intrafirm transfer, and loans decline moderately between 1 percent and 3 percent in the model, less than what we observe in the data. At the same time, consistent with our empirical observations, the balance sheet of US-based subsidiaries is unaffected by the shock that occurs in Europe, despite the large drop in parents' equity 25 Finally, the shock has a sizable negative effect on aggregate loans in the United States, which experience a decline of 4 percent.

This simple exercise is consistent with the changes in the balance sheets of branches and subsidiaries that we documented in Section 2, and hence raises our confidence in using the model to evaluate changes in regulatory policies. To this end, Table 7 illustrates the effects of a loan repayment shock under several interesting counterfactual scenarios. All the results are reported as percentage changes relative to the pre-crisis scenario, in industry equilibrium.

The first column in Table 7 is the same as in Table 6, where the shock hits the baseline calibrated economy. In the second column, we compute the response to the shock in the counterfactual scenario in which only subsidiarization is allowed. As expected, since subsidiaries in the model are isolated from the shock in Europe, lending in the United States does not decline in this scenario, while the

\footnotetext{
${ }^{25}$ The only changes in subsidiaries' loans and deposits are due to industry equilibrium responses to changes in the interbank rate.
} 
Table 6: Response to a Loan Repayment Shock in the Model

Percentage changes relative to baseline pre-crisis economy.

\begin{tabular}{lcc|ccc}
\hline & \multicolumn{2}{c}{$3.6 \%$ default } & \multicolumn{2}{c}{$E^{\prime}(a)=0.9 \times E(a)$} \\
& $\mathrm{PE}$ & $\mathrm{IE}$ & $\mathrm{PE}$ & $\mathrm{IE}$ \\
\hline Average P-B Parent Equity & 0.92 & 0.92 & 0.90 & 0.90 \\
Average Branch Wholesale Deposits & 0.91 & 0.88 & 0.88 & 0.87 \\
Average P-B Transfers & 1.08 & 1.13 & 1.09 & 1.11 \\
Average Branch Loans & 0.98 & 0.99 & 0.97 & 0.98 \\
\hline Average P-S Parent Equity & 0.81 & 0.81 & 0.90 & 0.90 \\
Average Subsidiary Retail Deposits & 1 & 0.99 & 1 & 1.00 \\
Average Subsidiary Loans & 1 & 1.01 & 1 & 1.01 \\
\hline Aggregate Loans & 0.96 & 0.96 & 0.96 & 0.96 \\
Interbank Rate & $0.84 \%$ & $0.80 \%$ & $0.84 \%$ & $0.82 \%$ \\
\hline
\end{tabular}

Table 7: Response to a Loan Repayment Shock in the Model Under Different Policy Scenarios

Percentage changes relative to baseline pre-crisis economy.

\begin{tabular}{lccccc}
\hline & $\begin{array}{c}\text { Baseline } \\
(3.6 \% \text { default })\end{array}$ & Only Subs & Only Branch & $\mathrm{k}=6 \%$ & $\begin{array}{c}\text { Monetary Policy } \\
\text { intervention }\end{array}$ \\
\hline Average P-B Parent Equity & 0.92 & - & 0.89 & - & 0.92 \\
Average Branch Wholesale Deposits & 0.88 & - & 0.88 & - & 0.79 \\
Average P-B Transfers & 1.13 & - & 1.03 & - & 1.39 \\
Average Branch Loans & 0.99 & - & 0.96 & - & 1.04 \\
\hline Average P-S Parent Equity & 0.81 & 0.84 & - & 0.84 & 0.81 \\
Average Subsidiary Retail Deposits & 0.99 & 0.97 & - & 0.99 & 0.94 \\
Average Subsidiary Loans & 1.01 & 1.03 & - & 1.01 & 1.08 \\
\hline Aggregate Loans & 0.96 & 1.02 & 0.94 & 0.99 & 1.02 \\
Interbank Rate Change & $-0.04 \%$ & $-0.08 \%$ & $-0.02 \%$ & $-0.02 \%$ & $-0.18 \%$ \\
\hline
\end{tabular}


decline in deposits is due to industry equilibrium effects acting through interest rate changes. The "subsidiaries only" economy is associated with aggregate loans that are 6 percent higher than in the baseline case: since subsidiaries' activities are independent from their parents, subsidiarization prevents the transmission of the European shock to the US economy. The third column shows the results of the opposite scenario, in which only branching is allowed. This is the scenario that has the most dramatic implications for the US banking sector: the shock generates a 12 percent decline in branch deposits, a 4 percent decline in branch lending, and a 6 percent decline in aggregate loans. This is a substantially larger effect when compared to the baseline case. This result is not surprising since branching is the organizational form that most facilitates the transmission of shocks across countries. In the fourth column, we report the effects of the shock under a counterfactual higher capital requirement: $k=0.06$. In the calibrated economy, this has the effect of reducing the incentives for branching, so all global banks open subsidiaries and the results are very similar to the ones in the subsidiaries-only case. Finally, in the last column, we illustrate the effects of the shock under an ad hoc monetary policy intervention: after the equity decline induced by the default, the Government makes a "helicopter drop" equal to 40 percent of the aggregate $M^{+}$. As a result of this intervention, the interbank rate decreases substantially, the transfers from parents to branches increases, and lending in the United States does not decline, contrary to the result in the baseline scenario.

\subsection{The International Transmission of Shocks: Intensive versus Extensive Mar- gin Adjustments}

While the analysis so far has focused on the European sovereign debt crisis, the structural model we developed in this paper allows us to think more broadly about how banks respond to episodes of crisis and the aggregate consequences for the international transmission of shocks. Figure 5 illustrates the implications of a generic and sizable shock to the parent banks' equity or revenues for the equilibrium selection in the model. The figure's left panel shows the equilibrium before the shock, with selection by efficiency into global status. The right panel illustrates selection in the post-shock economy. Following the shock, profits drop across the distribution of banks, but banks with differing global status show different responses. In particular, the fact that subsidiaries are separately capitalized limits the ability of parent-subsidiary conglomerates to reallocate resources internally, so the global profits of these banks are the most affected by the shock. On the other

hand, the internal capital market that allows parents and branches to easily reallocate resources 

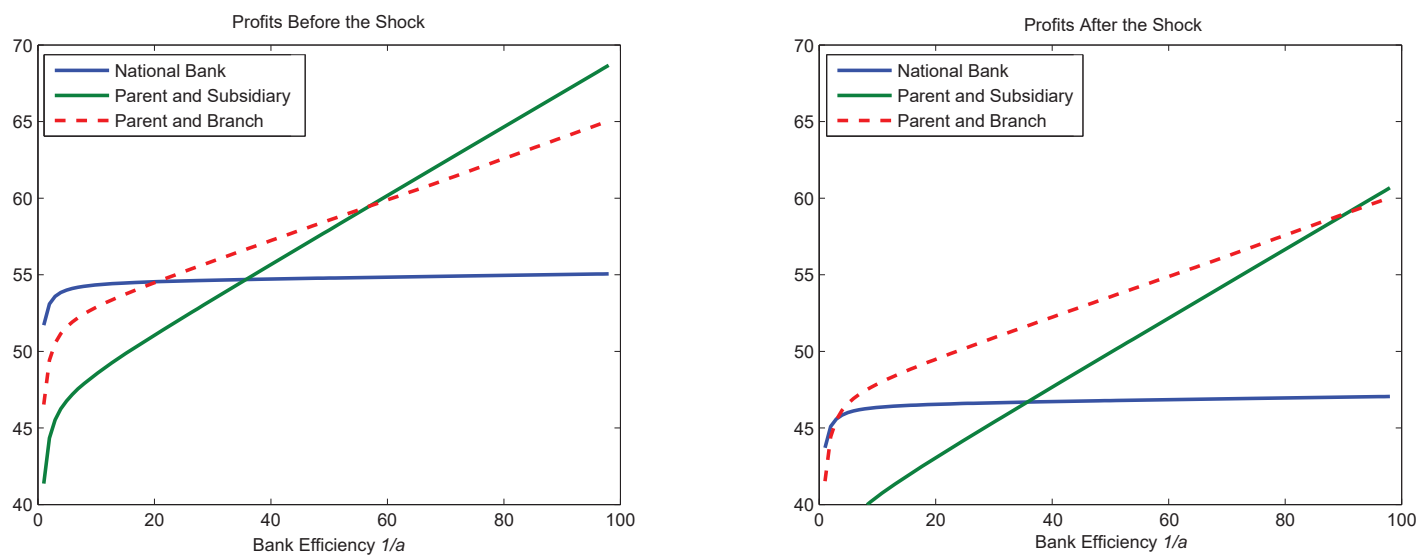

Figure 5: Equilibrium Profits Before and After a "Large" Shock to Parent Equity Source: Authors' calculations.

within the conglomerate across countries implies that their global profits decline less than those of the parent-subsidiary pairs.

Figure 5 implies that - for large enough shocks - it is more likely that a parent decides to shut down a subsidiary rather than a branch. Figure 6] shows suggestive evidence of this mechanism in the data. We superimpose the time series of parent equity-over-assets growth on a histogram reporting the exit rates of US-based branches and subsidiaries of European banks. It is clear from the figure that a) compared to branches, subsidiaries are unconditionally more likely to exit (consistent with the presence of frictions to asset repatriation), and b) periods of more pronounced exits tend to be periods when a parent's equity position declines.

Figure 6 provides external validity to the mechanism put forward in this paper. We can use these insights to evaluate the pros and cons of how the two different organizational forms may act as vehicles for shock transmission across countries. On the one hand, the counterfactual analysis of our model economy, based on intensive margin changes, shows that branches transmit shocks across countries through their internal capital market. However, the same internal capital market allows for international intrabank reallocations that may minimize the global consequences of a negative shock. On the other hand, subsidiaries are isolated from shocks to their parents in terms of their balance sheet adjustments on the intensive margin, but the presence of frictions to the internal capital market among the different units of the corporation makes global banks that own subsidiaries less resilient to the shock.

These different responses on the intensive and extensive margins make the task of regulating 


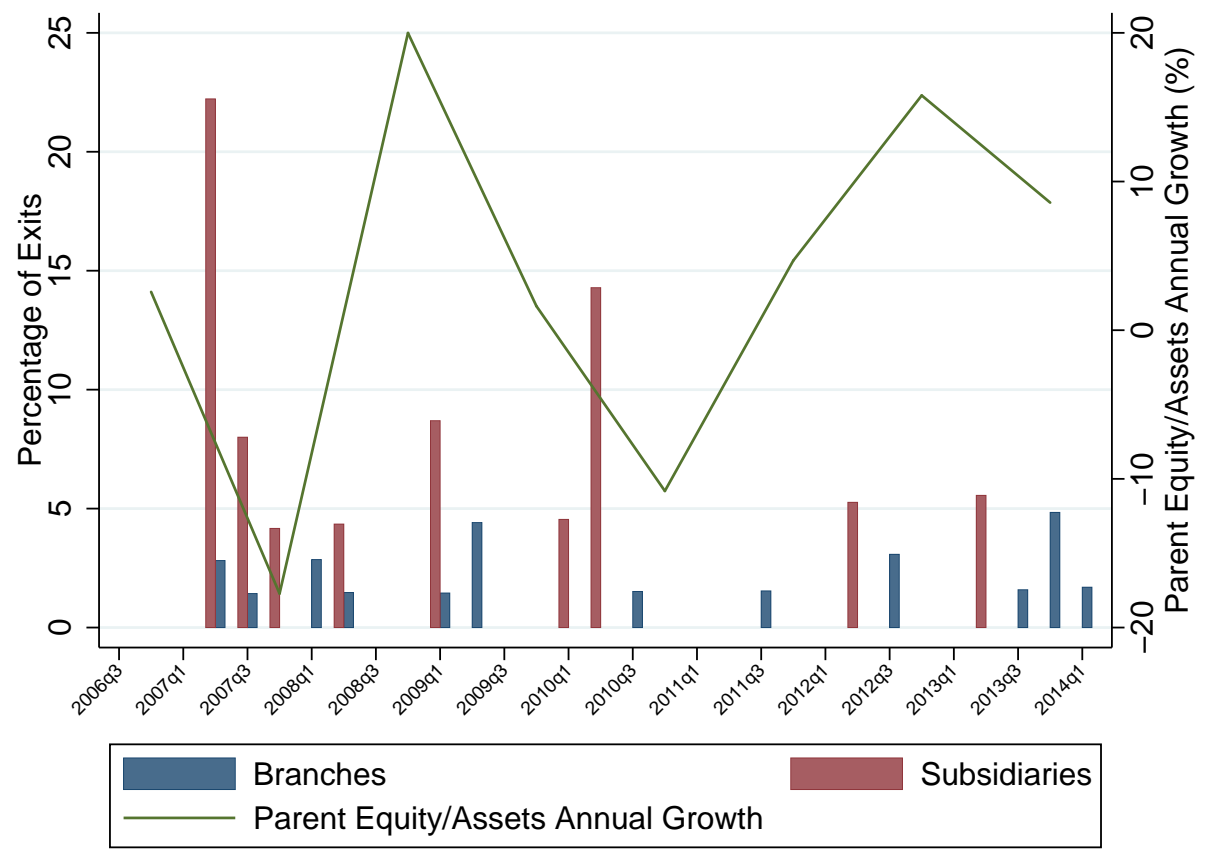

Figure 6: Exit and Equity Dynamics in the Data

Source: S\&P Global Market Intelligence and Call Reports.

global banks extremely difficult. Our analysis reveals that regulations have to balance a tradeoff between important policy priorities: limiting the transmission of shocks across countries and promoting the stability of large, globally important banks.

\section{Conclusions}

In this paper, we studied how different organizational forms of global banking - branching and subsidiarization - shape the transmission of shocks across countries. Our analysis focused on banks' endogenous choice to serve foreign markets via branching or subsidiarization.

We started by establishing a series of stylized facts about the cross-section of global banks and their response to the European sovereign debt crisis. Informed by the data, we developed a micro-founded structural model of foreign entry in the banking sector. The model explicitly distinguishes foreign banking institutions by their mode of operations, which is endogenous and responds to differences in cost structure, management efficiency, and banking regulations. This feature of the model allows us to highlight the economic channels through which banks' mode of 
operations matters for the extent of the transmission of various shocks across countries.

In order to study the effects of the European sovereign debt crisis through the lens of the theory, we calibrated the model and used it to perform a series of exercises that shed light on the implications of the current US regulatory framework for the extent of shock transmission. Our most important finding clarifies the relationship between global banks' organizational structure and shock transmission. We show that subsidiarization isolates a global bank's balance sheets by location; hence, subsidiarization minimizes contagion. However, subsidiarization is associated with a limited internal capital market between parent and affiliate, so that the parent does not have instruments to dampen the global effect of shocks, resulting in possible reorganizations and exits from the foreign market. Conversely, branching can take advantage of an internal capital market within the corporation and by smoothing the shock's effect across countries, reduces its global impact.

We see this paper as the starting point of a research agenda whose goal is to use careful quantitative analysis to inform the banking policy discussion. There are many important aspects of this problem which go beyond the scope of this paper, and we plan to tackle some of these issues in future research.

\section{References}

Bernard, Andrew B., J. Bradford Jensen, and Peter K. Schott. 2009. "Importers, Exporters, and Multinationals: a Portrait of Firms in the U.S. that Trade Goods." In Timothy Dunne and J. Bradford Jensen and Mark J. Roberts (eds.), Producer Dynamics: New Evidence from Micro Data. Chicago: University of Chicago Press.

Berrospide, Jose M, Ricardo Correa, Linda S Goldberg, and Friederike Niepmann. 2017. "International Banking and Cross-Border Effects of Regulation: Lessons from the United States." International Journal of Central Banking 13(2): 435-476.

Bremus, Franziska, Claudia M. Buch, Katheryn N. Russ, and Monika Schnitzer. 2013. "Big Banks and Macroeconomic Outcomes: Theory and Cross-Country Evidence of Granularity." Working Paper 19093. National Bureau of Economic Research.

Cerutti, Eugenio, Giovanni Dell'Ariccia, and Maria Soledad Martínez Pería. 2007. "How Banks go Abroad: Branches or Subsidiaries?" Journal of Banking and Finance 31(6): 1669-1692. 
Cetorelli, Nicola, and Linda Goldberg. 2011. "Global Banks and International Shock Transmission: Evidence from the Crisis." IMF Economic Review 59(1): 41-76.

Cetorelli, Nicola, and Linda Goldberg. 2012a. "Banking Globalization and Monetary Transmission." Journal of Finance 67(5): 1811-1843.

Cetorelli, Nicola, and Linda Goldberg. 2012b. "Follow the Money: Quantifying Domestic Effects of Foreign Bank Shocks in the Great Recession." American Economic Review: Papers and Proceedings 102(3): 213-218.

Claessens, Stijn, Asli Demirgüç-Kunt, and Harry Huizinga. 2001. "How Does Foreign Entry Affect Domestic Banking Markets?" Journal of Banking and Finance 25(5): 891-911.

Corbae, Dean, and Pablo D'Erasmo. 2013. "A Quantitative Model of Banking Industry Dynamics." Working Paper, University of Wisconsin Madison.

Correa, Ricardo, Horacio Sapriza, and Andrei Zlate. 2016. "Liquidity Shocks, Dollar Funding Costs, and the Bank Lending Channel during the European Sovereign Crisis." Federal Reserve Bank of Boston RPA Working Paper (16/04).

Danisewicz, Piotr, Dennis Reinhardt, and Rhiannon Sowerbutts. 2017. "On a Tight Leash: Does Bank Organizational Structure Matter for Macroprudential Spillovers?" Journal of International Economics 109: 174-194.

de Blas, Beatriz, and Katheryn N. Russ. 2013. "All Banks Great, Small, and Global: Loan Pricing and Foreign Competition." International Review of Economics and Finance 26: 4-24.

Dell'Ariccia, Giovanni, and Robert Marquez. 2010. "Risk and the Corporate Structure of Banks." Journal of Finance 65(3): 1075-1096.

Eaton, Jonathan. 1994. "Cross-Border Banking." Working Paper 4686. National Bureau of Economic Research.

Egan, Mark, Ali Hortacsu, and Gregor Matvos. 2017. "Deposit Competition and Financial Fragility: Evidence from the U.S. Banking Sector." American Economic Review 107(1): 169-216.

Fiechter, Jonathan, İnci Ötker Robe, Anna Ilyina, Michael Hsu, André Santos, and Jay Surti. 2011. "Subsidiaries or Branches: Does One Size Fit All?" IMF Staff Discussion Note (11/04). 
Goldberg, Linda. 2009. "Understanding Banking Sector Globalization." International Monetary Fund Staff Papers 56: 171-197.

Klein, Michael. 1971. "A Theory of the Banking Firm." Journal of Money, Credit and Banking 3(2): 205-218.

Monti, Mario. 1972. "Deposit, Credit, and Interest Rate Determination under Alternative Bank Objectives." In G.P. Szego and K. Shell (eds.), Mathematical Methods in Investment and Finance. Amsterdam: North Holland.

Niepmann, Friederike. 2015. "Banking Across Borders." Journal of International Economics 96(2): $244-265$.

Niepmann, Friederike. 2018. "Banking Across Borders with Heterogeneous Banks." CEPR Discussion Discussion Paper (DP12607).

Ongena, Steven, Ann L. Owen, and Judit Temesvary. 2018. "A Global Lending Channel Unplugged? Does U.S. Monetary Policy Affect Cross-border and Affiliate Lending by Global U.S. Banks?" Finance and Economics Discussion Series 2018-008. Board of Governors of the Federal Reserve System.

Peek, Joe, and Eric S. Rosengren. 2000. "Collateral Damage: Effects of the Japanese Bank Crisis on Real Activity in the United States." American Economic Review 90(1): 30-45. 


\section{Appendix}

\section{A The Regulatory Framework: History and Current Status}

The US Regulatory Framework has a long and complex history. We mention here those provisions that are relevant for the treatment of banks in our model.

\section{International Banking Act of 1978 (IBA)}

The IBA instituted the principle of national treatment, subjecting foreign banks to the same regulatory restrictions and benefits as domestic banks whenever possible. Prior to the IBA, the branches of foreign banks were not subject to federal restrictions on US banks, such as those on interstate banking (McFadden) and the separation of commercial and investment operations (Glass-Steagall). Foreign branches were not required to meet the reserve requirements of the Federal Reserve. However, they were ineligible for FDIC insurance, making it hard for them to compete for retail deposits. Foreign subsidiaries were already under federal regulatory authority. The IBA required foreign banks to choose a home state, then they became subject to the laws of that state and could not set up branches or subsidiaries in any other states. They also became subject to federal laws, which ended the competitive advantages they previously had over domestic banks. Under the IBA, all foreign banks that accepted retail deposits were now required to become part of the FDIC insurance system, but they could opt out of this requirement by not accepting retail deposits. These foreign branches that accepted retail deposits were now subject to the reserve requirements set by the Federal Reserve and subject to their examinations or that of a similar banking authority.

\section{Depository Institutions Deregulation and Monetary Control Act (DIDMCA) of 1980}

The DIDMCA expanded the influence of the Federal Reserve to all depository institutions, as opposed to only the approximately 40 percent of banks that were currently members of the Federal Reserve System. This meant nonmember banks had to meet the reserve requirements and assets and liabilities reporting requirements set by the Federal Reserve, similar to how the IBA applied these requirements to the US operations of foreign banks. These new requirements also allowed all depository institutions to enjoy the benefits of membership in the Federal Reserve System, 
including use of the discount window, a first for both foreign banks and nonmember banks.

\section{Foreign Bank Supervision Enhancement Act (FBSEA) of 1991}

The FBSEA, part of the Federal Deposit Insurance Corporation Improvement Act of 1991, prohibited new foreign bank branches in the United States from having access to the FDIC system and deposit insurance. This created a major operating difference from a foreign bank opening a new subsidiary, which was still able to offer deposit insurance. The FBSEA also expanded the Federal Reserve's authority to supervise and regulate foreign banks. The Federal Reserve could now examine any foreign-owned banking entities in the United States, which were now required to be examined annually by state or federal regulators, and granted the Federal Reserve greater privilege to access information about the parent companies. The act also allowed the Federal Reserve to terminate any unsafe foreign banking entity, whether it had a state or federal licence. To form a new banking entity in the United States, a foreign bank now needed the approval of the Federal Reserve independently of the organizational choice between a branch or a subsidiary..

\section{Riegle-Neal Interstate Banking and Branching Efficiency Act (IBBEA) of 1994}

The IBBEA overturned the McFadden Act (1927) by allowing interstate banking. Prior to this act, many states had passed laws allowing banks based in other states to operate within their state under specified conditions. The IBBEA set up a national framework to allow interstate banking under a standardized set of rules. For foreign-owned banks, this legislation meant a parent bank could set up branches in multiple states, or a subsidiary would be allowed to open branches in multiple states.

\section{New Intermediate Holding Company Regulation of 2016}

Starting in July, 2016, a foreign bank organization (FBO) with more than $\$ 50$ bn in US assets is required to designate an intermediate holding company (IHC) that holds the FBO's ownership interest in any of its US subsidiaries. The IHC is then subject to the regulatory requirements of any US bank holding company. Interestingly enough, foreign branches are left out of the IHC regulation

and branch assets do not count towards the regulatory thresholds, nor are branches subject to US regulatory requirements like the Dodd-Frank Act's stress testing, Basel III capital requirements, 
etc. Foreign branches operating in the United States remain subject to regulation in their home country.

\section{B Data Description}

\section{US Office-Level Data}

Our office-level data comes from two different forms, FFIEC 031 and FFIEC 002. FFIEC 031 is formally known as the Consolidated Reports of Condition and Income for a Bank with Domestic and Foreign Offices, often referred to as Call Reports. This is our source for data on the financial positions of foreign-owned subsidiaries operating in the United States. FFIEC 002 is formally known as the Report of Assets and Liabilities of US Branches and Agencies of Foreign Banks, and is our source for the data on the financial positions of foreign-owned branches.

We complement this data with the Federal Reserve Board's Structure and Share Data for US Offices of Foreign Banks. The Structure Data is US office-level data of foreign banking organizations covering selected variables from the FFIEC 031 and FFIEC 002, including the "top-tier" foreign parent bank and country, as well as US office type and assets. This source allows us to identify the two types of organizational forms that are the object of this study, branches and subsidiaries. We define uninsured federal branches and uninsured state branches as "branches." "Subsidiaries" encompass state member banks, state nonmember banks, national banks, state savings banks, and federal savings banks. The Share Data contains summary statistics on the fraction and level of total assets, commercial and industrial loans, total loans or deposits in domestic-owned banks, foreign-owned banks (subsidiaries) and foreign-owned branches and agencies.

Balance sheet data for subsidiaries in our sample come from the form FFIEC 031. Specifically, we construct retail deposits as the sum of rconf049, the amount of deposits (excluding retirement accounts) of $\$ 250,000$ or less, and rconf045, the amount of retirement deposit accounts of $\$ 250,000$ or less. Wholesale deposits are given by the sum of rconf051, the amount of deposits (excluding retirement) above $\$ 250,000$, and rconf04\%, the amount of retirement deposit accounts above $\$ 250,000$. The sum of wholesale and retail deposits gives our measure of total deposits. Finally, rcfd2122 (loans and leases net of unearned income) measures total net loans.

Form FFIEC 002 provides additional information on foreign-owned branches. Specifically, 
wholesale deposits are given by rcon1653 (total deposits and credit balances in transaction accounts of the branch), while rcfd2122 (loans and leases net of unearned income) is our measure of total net loans. The intrabank transfer is computed using data on the flow of funds between parent and branches: rcfd2944 reports the balance due to their parent institution and rcfd2154 the balance due from their parent institution.

\section{European Bank-Level Data}

S\&P Global Market Intelligence (formerly SNL Financial) is our data source on European banks. Using bank names, we were able to match this data with the European parents of US offices in the Structure data: there are 56 European "top-tier" parent banks in our matched dataset. The variables we use from S\&P Global Market Intelligence are total assets (S\&P Key field 132264), total deposits (132288), total net loans (132214), interest earned on loans (132532) and interest expense on deposits (133820.)

\section{Exposure Data}

Exposures for "top-tier" parent banks are contained in the European Banking Authority (EBA) stress test data, which reports the total value of each bank's holdings of sovereign debt in each European country. Only 50 of our 56 European parents participated in these stress tests. For this reason, we construct two different definitions of a parent bank's exposure to the European sovereign debt crisis . According to our baseline definition, any parent bank with above median holdings of government debt from Greece, Italy, Ireland, Portugal, or Spain is considered exposed to the crisis, while all other parent banks are not. An alternative definition considers any parent bank in a country using the euro to be exposed, while all other parent banks are not. This second definition does not require EBA stress test data.

\section{Additional Empirical Evidence}

This Appendix reports additional evidence that supports the broad patterns that we document in the body of the paper.

Figure C.1 shows aggregate data on the population of foreign banking organizations operating 
in the United States.
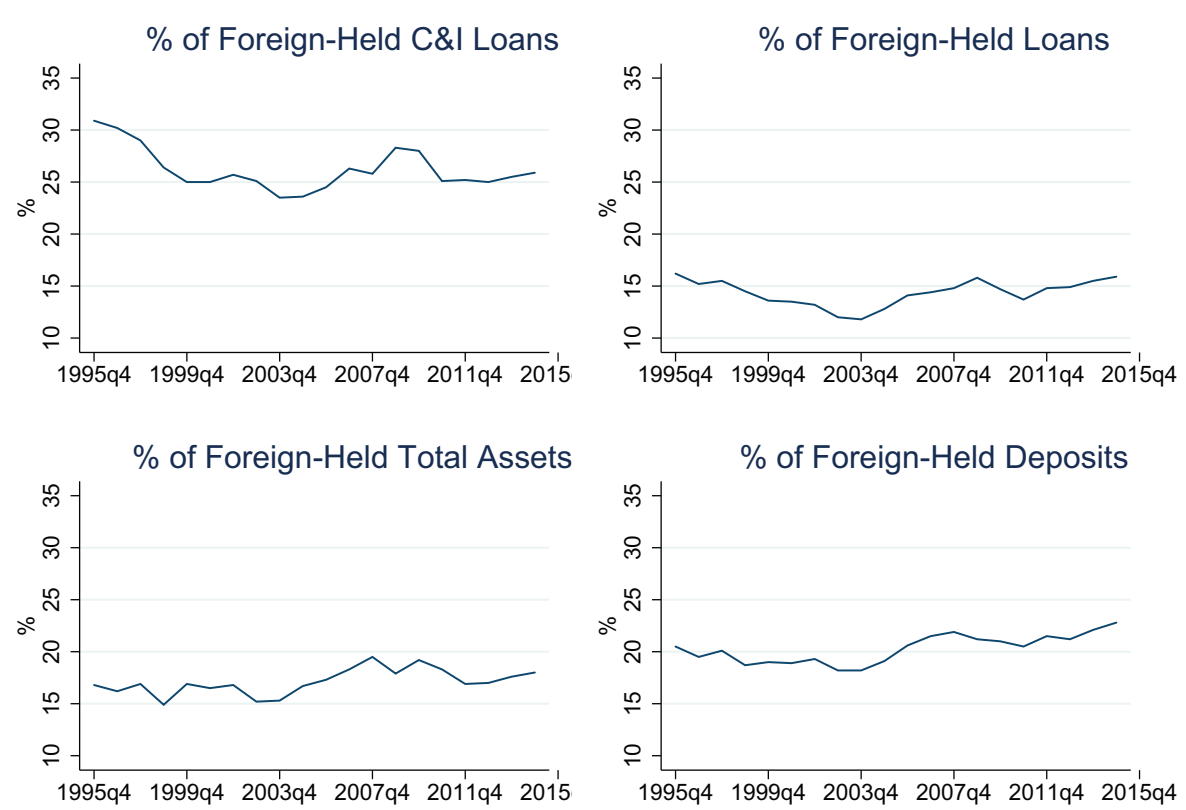

Figure C.1: Percentage of Assets, Commercial and Industrial Loans, Total Loans, and Deposits Held in FBOs in the United States

Source: Structure Data for US Offices of Foreign Banking Organizations - Selected Assets and Liabilities of Domestic and foreign-owned US Commercial Banks plus US Branches and Agencies of Foreign Banks.

In Section 2 we show large size differences between branches and subsidiaries of foreign banks. Figure C.2 illustrates that these size differences are not driven by a few firms holding extraordinarily large balance sheets, but hold throughout the entire distribution of banks: the deposit, loan, and asset size distributions in foreign subsidiaries first-order stochastically dominate the analogous distributions in foreign branches.

To support the model's assumption that banks "transfer" their managerial efficiency when establishing foreign operations, Figure C.3 shows that the amount of assets a foreign bank holds in the United States is positively related to its size in its home market.

Figure C.4 illustrates the evolution of intrafirm flows by bank exposure and also by home country to illustrate that banks from non-GIIPS countries were also involved in the flow reversal we document in Section 2 .

The calibration analysis presented in Section 4 argues that equity of European parents broadly 

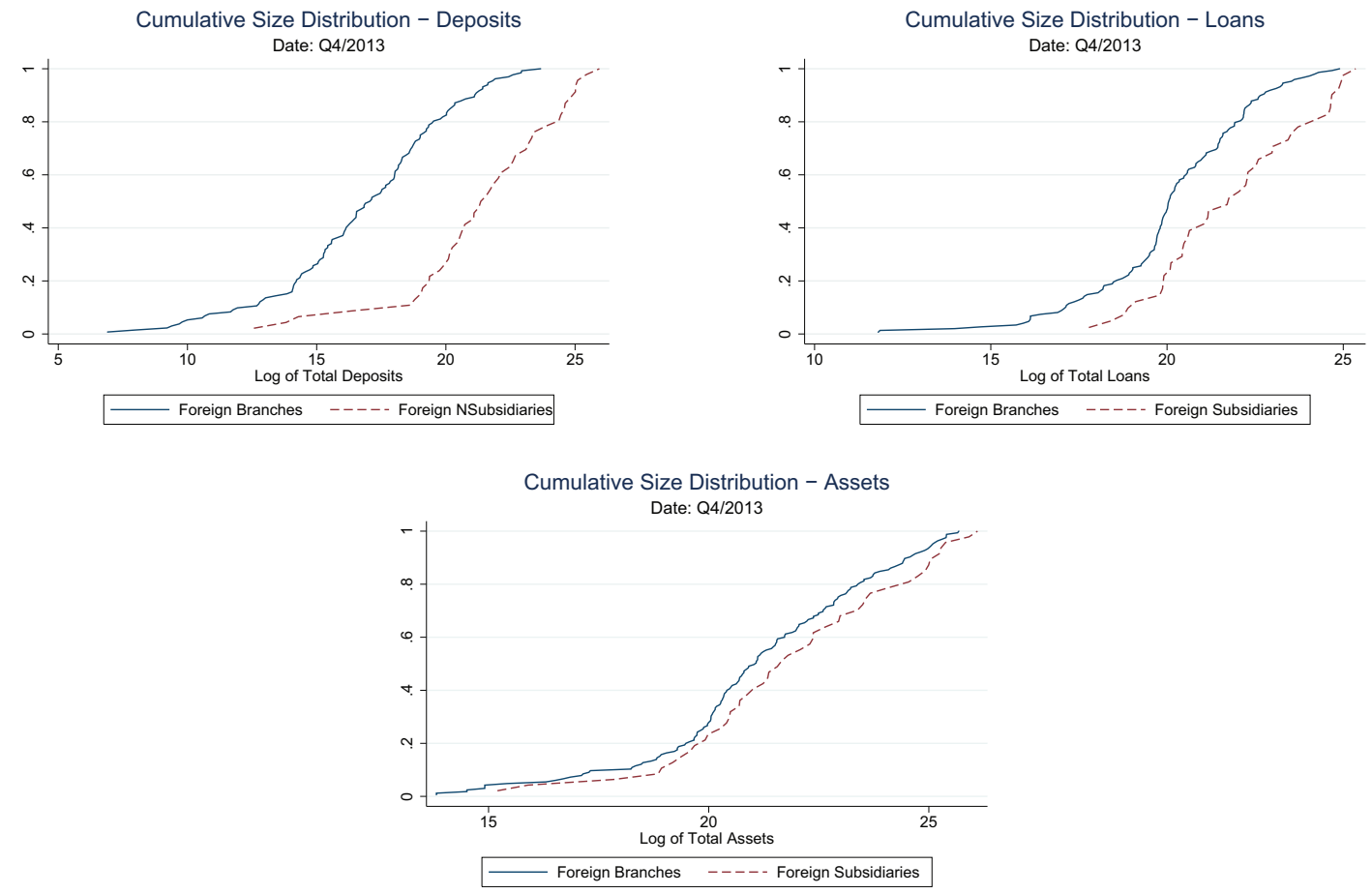

\section{Figure C.2: Size Distributions}

Cumulative distribution functions for deposits, loans, and assets, respectively, held in foreign-owned subsidiaries and branches in 2013:Q4.

Source: US Structure Data for US Offices of Foreign Banking Organizations - Selected Assets and Liabilities of Domestic and Foreign-Owned US Commercial Banks plus US Branches and Agencies of Foreign Banks. 


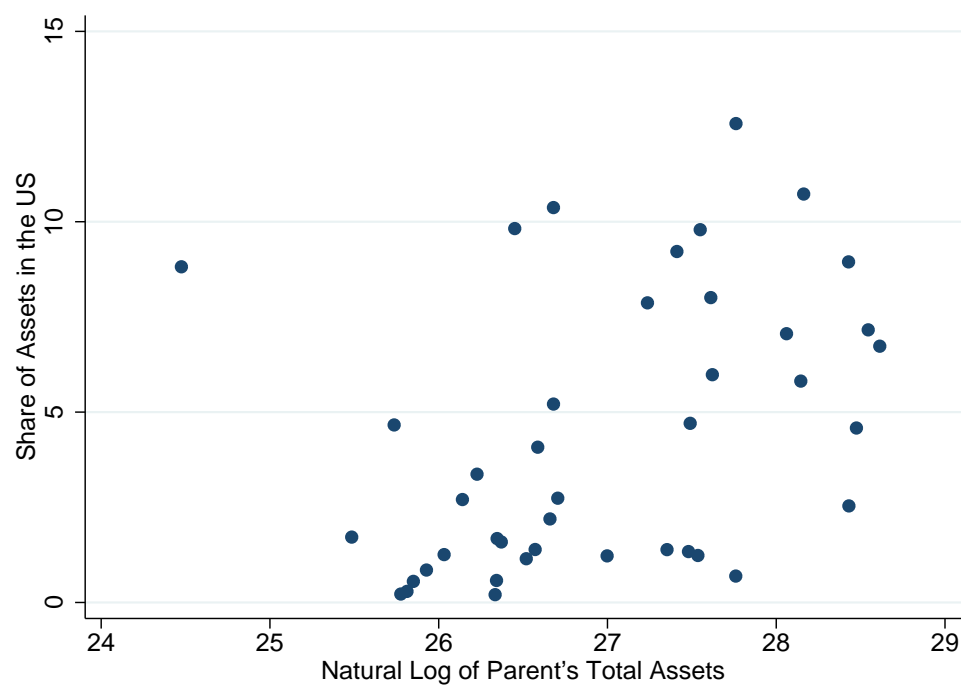

Figure C.3: Size of Domestic versus Foreign Assets

Share of US assets in a parent's total assets versus the parent's size.

Source: S\&P Global Market Intelligence data for top-tier European parents of US branches and subsidiaries, 2013.

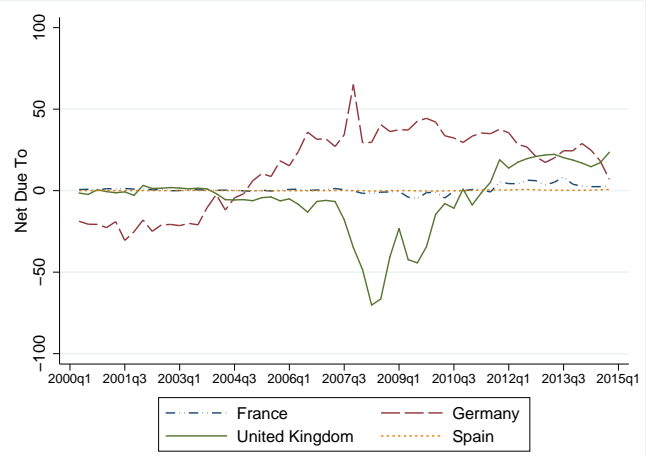

(a) Nonexposed Banks

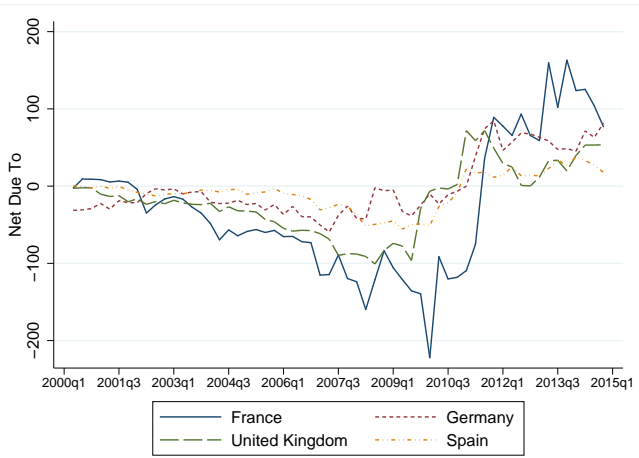

(b) Exposed Banks

\section{Figure C.4: Net Intrafirm Flows by Country of Origin}

Difference between Net due from related depository institutions and Net due to related depository institutions (items 2 and 5, respectively, from the "Schedule RAL-Assets and Liabilities"), broken down by parent exposure and by country of origin.

Data source: Report of Assets and Liabilities of US Branches and Agencies of Foreign Banks (FFIEC 002). All values are expressed in billions. 
increased after the EBA's introduction of stress testing, but fell at the onset of the sovereign debt crisis. Figure C.5 illustrates these trends.

Finally, for completeness, Table C.1 lists the European parents included in our sample from 2010, together with the number of branches and subsidiaries that each bank had at that point, and with the share of assets in each of the two organizational forms.

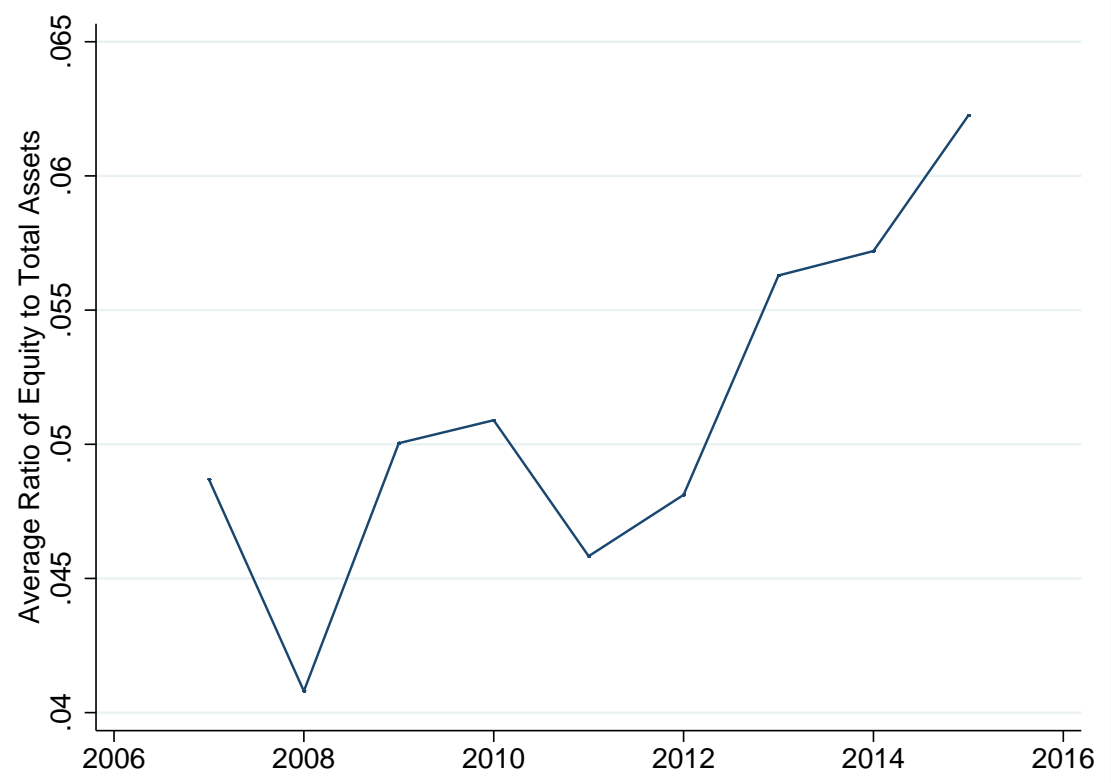

Figure C.5: Parent Equity over Assets

Average equity over assets held in European parents of foreign banking organizations in the United States.

Source: S\&P Global Market Intelligence. 
Table C.1: List of European Parents in Our Sample, Data for 2010

\begin{tabular}{|c|c|c|c|c|}
\hline Bank Name & No. of Subs & No. of Branches & $\begin{array}{c}\% \text { of Assets } \\
\text { in Subs. }\end{array}$ & $\begin{array}{l}\% \text { of Assets } \\
\text { in Branches }\end{array}$ \\
\hline Allianz Se & 0 & 2 & 0 & 100 \\
\hline Allied Irish Banks, P.L.C. & 2 & 1 & 96.11 & 3.89 \\
\hline Banco Bilbao Vizcaya Argentaria, S.A. & 1 & 1 & 72.31 & 27.69 \\
\hline Banco Comercial Portugues, S.A. & 1 & 0 & 100 & 0 \\
\hline Banco De Sabadell, S.A. & 2 & 1 & 64.92 & 35.08 \\
\hline Banco Popular Espanol, S.A. & 1 & 0 & 100 & 0 \\
\hline Banco Santander, S.A. & 1 & 3 & 72.26 & 27.74 \\
\hline Barclays Plc & 1 & 2 & 14.08 & 85.92 \\
\hline Bayerische Landesbank & 0 & 1 & 0 & 100 \\
\hline BNP Paribas & 2 & 5 & 36.15 & 63.85 \\
\hline BPCE & 0 & 1 & 0 & 100 \\
\hline Caisse Federale De Credit Mutuel & 0 & 1 & 0 & 100 \\
\hline Caixa De Aforros De Vigo, Ourense E Pontevedra & 0 & 1 & 0 & 100 \\
\hline Caixa Geral De Depositos, S.A. & 0 & 1 & 0 & 100 \\
\hline Bancaja & 0 & 1 & 0 & 100 \\
\hline Caja De Ahorros Y Monte De Piedad De Madrid & 1 & 0 & 100 & 0 \\
\hline Cooperatieve Centrale Raiffeisen-Boerenleenbank B.A. & 1 & 1 & 12.09 & 87.91 \\
\hline Credit Agricole Corporate And Investment Bank & 0 & 2 & 0 & 100 \\
\hline Credit Suisse Group & 0 & 1 & 0 & 100 \\
\hline Deutsche Bank Aktiengesellschaft & 2 & 1 & 26.93 & 73.07 \\
\hline Dexia S.A. & 0 & 1 & 0 & 100 \\
\hline DNB Nor Asa & 0 & 1 & 0 & 100 \\
\hline DZ Bank Ag Deutsche Zentral-Genossenschaftsbank & 0 & 1 & 0 & 100 \\
\hline Erste Group Bank Ag & 0 & 1 & 0 & 100 \\
\hline Espirito Santo Control S.A. & 1 & 2 & 24.14 & 75.86 \\
\hline Fondazione Monte Dei Paschi Di Siena & 0 & 1 & 0 & 100 \\
\hline Governor And Company Of The Bank Of Ireland, The & 0 & 1 & 0 & 100 \\
\hline HSBC Holdings Plc & 3 & 0 & 100 & 0 \\
\hline HSH Nordbank Ag & 0 & 1 & 0 & 100 \\
\hline Hypo Real Estate Holding Ag & 0 & 1 & 0 & 100 \\
\hline Intesa Sanpaolo S.P.A. & 0 & 1 & 0 & 100 \\
\hline KBC Bank Nv & 0 & 1 & 0 & 100 \\
\hline Landesbank Baden-Wuerttemberg & 0 & 1 & 0 & 100 \\
\hline Landesbank Hessen-Thuringen Girozentrale & 0 & 1 & 0 & 100 \\
\hline Lloyds Banking Group Plc & 0 & 2 & 0 & 100 \\
\hline Niedersaechsischer Sparkassen- Und Giroverband & 0 & 1 & 0 & 100 \\
\hline
\end{tabular}

Continued on next page 
Table C.1 - Continued from previous page

\begin{tabular}{|c|c|c|c|c|}
\hline Bank Name & No. of Subs & No. of Branches & $\begin{array}{c}\% \text { of Assets } \\
\text { in Subs. }\end{array}$ & $\begin{array}{l}\% \text { of Assets } \\
\text { in Branches }\end{array}$ \\
\hline Nordea Bank Ab (Publ) & 0 & 2 & 0 & 100 \\
\hline Nrw.Bank & 0 & 1 & 0 & 100 \\
\hline Piraeus Bank S.A. & 1 & 0 & 100 & 0 \\
\hline Royal Bank Of Scotland Group Plc, The & 2 & 4 & 62.66 & 37.34 \\
\hline Skandinaviska Enskilda Banken Ab (Publ) & 0 & 1 & 0 & 100 \\
\hline Societe Generale & 0 & 2 & 0 & 100 \\
\hline Standard Chartered Plc & 0 & 2 & 0 & 100 \\
\hline Svenska Handelsbanken Ab (Publ) & 0 & 1 & 0 & 100 \\
\hline Swedbank Ab & 0 & 1 & 0 & 100 \\
\hline UBS Ag & 1 & 7 & 32.48 & 67.52 \\
\hline Unicredit S.P.A. & 0 & 2 & 0 & 100 \\
\hline
\end{tabular}

\section{Details on the Construction and Solution of the Model}

\section{D.1 Modeling Deposit Insurance}

As described in Section 3, all banks accepting retail deposits in the United States have to pay deposit insurance to the Federal Deposit Insurance Corporation (FDIC), an independent US agency, created by Congress, in charge of insuring deposits. The main goal of deposit insurance is to prevent bank runs. Deposit insurance also generates moral hazard problems - since bank deposits are insured, bankers have incentives to engage in riskier behavior. The classic way to address this moral hazard problem and ultimately reduce the risks of bankruptcies is to price the deposit insurance at the actuarially fair rate. Thus, in order to achieve a certain level of actuarial fairness, modern deposit insurance is not paid as a flat fee on insured deposits, but rather is assessed based on the risk profile of a bank's assets and funding sources. Under the Dodd-Frank Act, the FDIC assessment is applied to all assets of a bank less its tangible equity (the assessment base), so banks pay additional insurance even if their source of additional funding is not itself insured.

Small banks are classified based on their riskiness according to the CAMELS rating system of broad risk measures and assigned a risk category based on these measures 11 Table D.1 reports the

\footnotetext{
${ }^{1}$ CAMELS is a supervisory rating system developed by US regulatory agencies in which capital adequacy, assets, management capability, earnings, liquidity, and sensitivity to market risk are assigned a rating from 1 (best) to 5 (worst). A rating of 5 indicates that the bank's problems are beyond management's ability to control or correct.
} 
current rates by risk-category:

Table D.1: FDIC Assessment Rates by Risk Categories, in Basis Points Source: https://www.fdic.gov/deposit/insurance/assessments/proposed.html.

\begin{tabular}{cccccc}
\hline & I & II & III & IV & Total \\
\hline Assessment Rate & 2.5 to 9 & 9 to 24 & 18 to 23 & 30 to 45 & 2.5 to 45 \\
\hline
\end{tabular}

Larger banks and complex institutions are subject to the same total range of rates, but are assessed based on the following three factors. The CAMELS rating constitutes 30 percent of the bank's assessment rate, and the rest of the rate is calculated according to a formula based on factors related to asset risk and funding risk (50 and 20 percent, respectively). The asset risk measures generally punish higher leverage, riskier classes of assets, and asset concentration in a particular sector. The funding risk measures generally reward having a larger share of funding from insured deposits and holding highly liquid assets, on the theory that such funding is less likely to flee in crisis. These formulaic measures are similar in nature to the categories assessed subjectively in the CAMELS rating.

Our proposed reduced-form expression in equation (4) follows the principles of the FDIC Current Assessment Rate Calculator for Highly Complex Institutions, available at: https://www.fdic.gov/deposit/insurance/calculator.html.

The highly complex institutions pricing scorecard lists three criteria as building blocks of the CAMELS rating system: 1) the ability to withstand asset-related stress; 2) the ability to withstand funding-related stress; and 3) potential loss severity. Our formulation follows the second criterion, the ability to withstand funding-related stress:

$$
I P(D, L, M)=\underbrace{f_{p}\left(D, M^{-}, E(a)\right)}_{\text {assessment rate }} \cdot \underbrace{\left(L+M^{+}-E(a)\right)}_{\text {assessment base }} \equiv\left[R_{\text {min }}+f_{p} \cdot \frac{M^{-}}{E(a)}\right] \cdot\left(L+M^{+}-E(a)\right),
$$

where $R_{\text {min }}>0$ and $f_{p}>0$. We abstract from the exact formulas for calculating the FDIC assessment rate, and adopt a functional form that results in an insurance premium that is higher the more that a bank resorts to the interbank borrowing as a share of bank equity in order to fund its activities. This formula applies to local banks, subsidiaries, and parents of subsidiaries. The analogous formula for parents of branches includes both parent and branch loans in its assessment base. 


\section{D.2 The Bank's Profit Maximization Problem: A Parametric Example}

In order to illustrate some properties of the bank's problem, in this section we resort to a parametric example (which exploits the same parameterization we use in the calibration).

Like in the calibration, we assume a constant elasticity loan demand function: $L\left(r_{L}\right)=r_{L}^{-\varepsilon} A$, where $\varepsilon>1$ is the elasticity of loan demand, and $A$ is a parameter describing the aggregate size of the market for loans. Similarly, we assume a constant elasticity retail deposit supply function: $D\left(r_{D}\right)=r_{D}^{\vartheta} B$, where $\vartheta>0$ is the elasticity of retail deposit supply, and $B$ is a parameter describing the aggregate size of the retail deposits market. We also assume a linear separable management cost function: $C(D, L)=c_{L} L+c_{D} D$, where $c_{L}, c_{D}>0$. The deposit insurance premium takes the functional form described in the previous section. Under these assumptions, if a local bank is a lender in the interbank market $(M>0)$, its optimal loans and deposits in the unconstrained equilibrium are given by 2

$$
\begin{aligned}
L_{N}^{u}(a) & =\left\{\frac{\varepsilon}{p(\varepsilon-1)}\left[(1-p)+r_{M}+a c_{L}\right]\right\}^{-\varepsilon} A \\
D_{N}^{u}(a) & =\left\{\frac{\vartheta}{(\vartheta+1)}\left[\left(r_{M}-a c_{D}-R_{\text {min }}\right]\right\}^{\vartheta} B,\right.
\end{aligned}
$$

and maximal profits are:

$$
\pi_{N}(a)=r_{M} E(a)+H_{1}(\varepsilon, p)\left[(1-p)+r_{M}+a c_{L}\right]^{1-\varepsilon} A+H_{2}(\vartheta)\left(r_{M}-a c_{D}-R_{\min }\right)^{1+\vartheta} B,
$$

where $H_{1}(\cdot)$ and $H_{2}(\cdot)$ are functions of model parameters only. Equation (D.4) shows that a bank's optimal profits are increasing in bank efficiency $1 / a$ and in the bank's equity $E(a)$.

\section{D.3 Constrained Equilibrium in Local Banks}

In the model, the constrained equilibrium has two possible configurations, depending on whether the bank borrows or lends in the interbank market. We describe both configurations using the parameterization introduced in the previous section.

\section{Constrained equilibrium with interbank lending.}

\footnotetext{
${ }^{2}$ The intuition that this special example conveys is the same in the case in which a bank is a borrower in the interbank market, just less transparent algebraically.
} 
If the bank is a lender in the unconstrained equilibrium $\left(M_{N}^{u}>0\right)$, it could be also a lender in the constrained one. In this constrained equilibrium scenario, a bank's loans to its customers and to the interbank market enter the expression for risk-weighted assets, so that $M_{N}^{c}(a)=$ $\frac{E(a)}{\omega_{M} k}-\frac{\omega_{L}}{\omega_{M}} L_{N}^{c}$. Deposits adjust to clear the resource constraint: $D_{N}^{c}(a)=\left(1-\frac{\omega_{L}}{\omega_{M}}\right) L_{N}^{c}-$ $\left(1-\frac{1}{\omega_{M} k}\right) E(a)$, while constrained loans solve:

$$
\begin{aligned}
& L_{N}^{c}(a)=\left\{\frac { \varepsilon } { p ( \varepsilon - 1 ) } \left[(1-p)+\frac{\omega_{L}}{\omega_{M}} r_{M}+a c_{L}+\left(a c_{D}+R_{\min }\right)\left(1-\frac{\omega_{L}}{\omega_{M}}\right)+\ldots\right.\right. \\
&\left.\left.\frac{\vartheta}{\vartheta+1}\left[\left(1-\frac{\omega_{L}}{\omega_{M}}\right) L_{N}^{c}-\left(1-\frac{1}{\omega_{M} k}\right) E(a)\right]^{1 / \vartheta} B^{-1 / \vartheta}\left(1-\frac{\omega_{L}}{\omega_{M}}\right)\right]\right\}^{-\varepsilon} A .
\end{aligned}
$$

If the resulting $M^{c}>0$, these conditions characterize the constrained equilibrium. Otherwise, the constrained equilibrium will be one that displays interbank borrowing.

2. Constrained equilibrium with interbank borrowing.

If the constrained equilibrium found above is inconsistent, or if the bank is a borrower in the unconstrained equilibrium, it will also be a borrower in the constrained equilibrium.

Under this scenario, the amount of loans is the maximum that the capital requirement allows:

$$
L_{N}^{c}(a)=E(a) /\left(\omega_{L} k\right)
$$

where deposits adjust depending on the first-order condition, and interbank borrowing clears the resource requirement:

$$
M_{N}^{c}=D_{N}^{c}+\left(1-\frac{1}{\omega_{L} k}\right) E
$$

\section{D.4 Modeling the Wholesale Deposits Supply}

Egan. Hortacsu, and Matvos (2017) show that the demand for uninsured wholesale deposits is less elastic than the one for insured retail deposits, and that wholesale deposits are sensitive to some measure of the banking organization "distress." We rely on their estimates and embed them in a parametric form of wholesale deposits supply that is consistent with their findings. Our modelbased measure of bank distress is inversely related to the additional buffer on capital requirement that banks hold in normal times, given by equity over risk-weighted assets $(R W A)$ divided by the capital requirement, $k$. When $\frac{E(a)}{k \cdot R W A}=1$, the capital requirement is binding and the bank 
experiences maximum distress, resulting in a flight of wholesale deposits. Distress decreases as $\frac{E(a)}{k \cdot R W A}$ grows bigger than one.

We choose the following functional form for the demand of wholesale deposits:

$$
D_{w}^{*}=\left(r_{D}^{* w}\right)^{\vartheta_{w}} \log \left(\frac{E(a)}{k \cdot R W A}\right) B
$$

where $\vartheta_{w}<\vartheta$ is the elasticity of wholesale deposits, and $B_{w}$ is a parameter describing the aggregate size of the wholesale deposits market. This functional form implies that the quantity of deposits supplied falls as the buffer on the capital requirement decreases, and that there is a complete deposits flight $\left(D_{w}^{*}=0\right)$ when the capital requirement is binding.

For comparison purposes, Figure D.1 plots the retail deposit supply and the wholesale deposit supply for different values of the buffer on capital requirement.

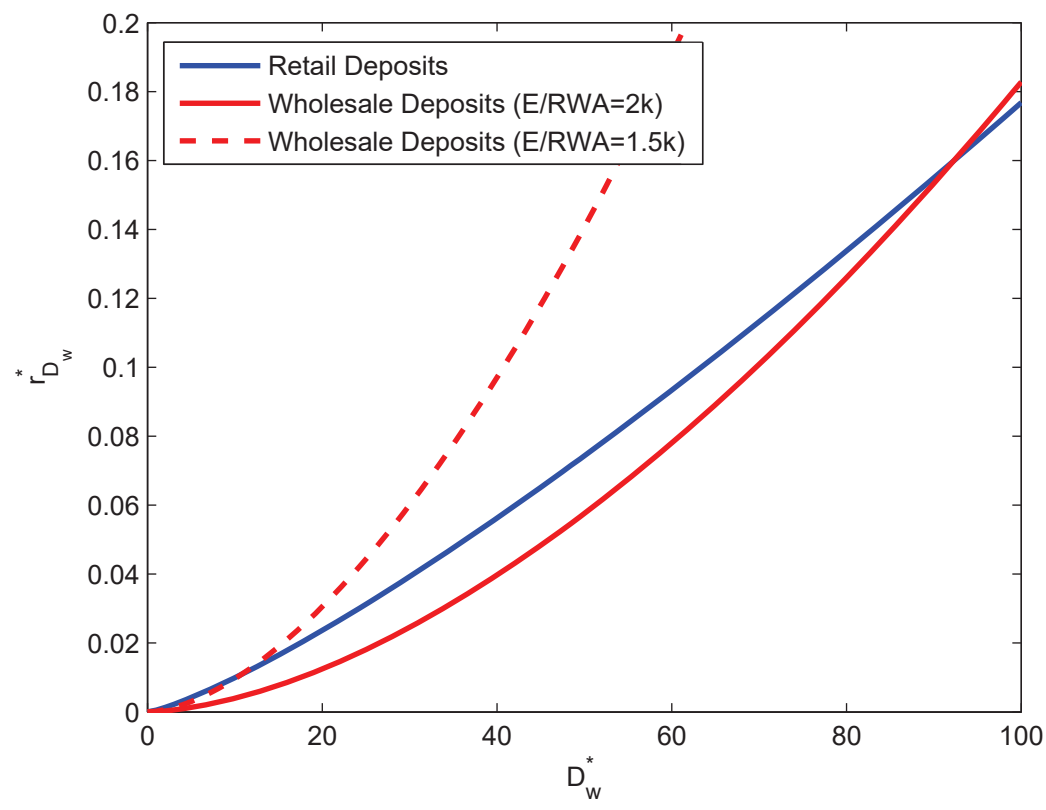

Figure D.1: Retail and Wholesale Deposit Supply 


\section{E Details of the Calibration Procedure}

\section{E.1 Calibrating Banks' Efficiency Distribution}

We start by assessing which parametric distribution better approximates the empirical distribution of interest revenues from loans. We estimate the parameters of said distribution under these alternate assumptions: Pareto, log-normal, Fréchet, and Weibull. With the estimated distributions, we run Anderson-Darling tests of the hypothesis that each of these parametric distributions well approximates the empirical distribution. While we can reject the hypotheses that the distribution of interest revenues from loans is Pareto, Fréchet or Weibull, we cannot reject the hypothesis that the distribution is log-normal. Based on this result, we need to establish a theoretical linkage between the distribution of interest revenues from loans and the banks' efficiency distribution.

Assume that banks' efficiency $x \equiv 1 / a$ is distributed log-normal: $\log (x) \sim \mathcal{N}(\mu, \sigma)$. In the unconstrained equilibrium, and under the assumption that a bank is lending in the interbank market, revenues from domestic loans are:

$$
r_{L} \cdot L=\left[\frac{\varepsilon}{p(\varepsilon-1)}\left[a c_{L}+r_{M}+(1-p)\right]\right]^{1-\varepsilon} A .
$$

Assuming that the term $\left(r_{M}+1-p\right)$ is "small" relative to $a c_{L}$, revenues from loans can be approximated as:

$$
r_{L} \cdot L \approx\left[\frac{\varepsilon}{p(\varepsilon-1)} a c_{L}\right]^{1-\varepsilon} A=H a^{1-\varepsilon}=H x^{\varepsilon-1},
$$

where $H \equiv\left[\frac{\varepsilon c_{L}}{p(\varepsilon-1)}\right]^{1-\varepsilon} A$. Hence:

$$
\log \left(r_{L} \cdot L\right) \approx \log (H)+(\varepsilon-1) \log (x),
$$

where $\log (x) \sim \mathcal{N}(\mu, \sigma)$ implies that $\log \left(r_{L} \cdot L\right) \sim \mathcal{N}\left(\mu_{L}, \sigma_{L}\right)$. As a result, the distribution of interest revenues from loans can be approximated by a log-normal distribution with parameters:

$$
\begin{aligned}
& \mu_{L}=(\varepsilon-1) \mu+\log (H) \\
& \sigma_{L}=(\varepsilon-1) \sigma .
\end{aligned}
$$

The maximum-likelihood estimates, conditional on the distribution of the interest revenues from loans being log-normal, deliver $\mu_{L}=5.96$ and $\sigma_{L}=1.93$. Then we impose that $\mu_{L}=(\varepsilon-1) \mu+$ 
$\log (H)=19.78$ and $\sigma_{L}=(\varepsilon-1) \sigma=1.93$ in the calibration.

\section{E.2 Jointly Calibrated Parameters}

Table E.1 reports the parameters that are calibrated to match the moments of interest. The implied parameters of the efficiency distribution, from equations (E.2) and (E.3), are $\mu=5.4, \sigma=0.57$.

Table E.1: Calibrated Parameters

\begin{tabular}{lll}
\hline Parameter & Definition & Value \\
\hline$c_{L} / c_{D}$ & Unit Management Cost & 12.5 \\
$\varepsilon$ & Elasticity of Loan Demand & 4.4 \\
$A^{*}$ & Loan Demand Shifter & $5.52 \times 10^{-2}$ \\
$B^{*}$ & Retail Deposit Demand Shifter & $1.28 \times 10^{5}$ \\
$B_{w}^{*}$ & Wholesale Deposit Demand Shifter & $2.31 \times 10^{4}$ \\
$F_{S}$ & Fixed Cost of Subsidiarization & 167 \\
$F_{B}$ & Fixed Cost of Branching & 142 \\
\hline
\end{tabular}

